\title{
13. LATE CENOZOIC DIATOM BIOSTRATIGRAPHY AND PALEOCEANOGRAPHY OF THE MIDDLE-LATITUDE EASTERN NORTH PACIFIC, DEEP SEA DRILLING PROJECT LEG 63 $^{1}$
}

\author{
John A. Barron, U.S. Geological Survey, Menlo Park, California
}

\begin{abstract}
Middle Miocene and upper Miocene diatoms recovered during Deep Sea Drilling Project Leg 63 allow refinement of eastern North Pacific diatom biostratigraphy and permit several ties with low-latitude biostratigraphy. Numerous datum levels provide excellent correlation between individual Leg 63 sites $\left(23^{\circ} \mathrm{N}-34^{\circ} \mathrm{N}\right)$ and with Site $173\left(40^{\circ} \mathrm{N}\right)$ off northern California. Three intervals of widespread hiatus development appear to be related to intensification of bottom-water activity (erosion and/or corrosion) associated with growth of the Antarctic ice sheet. These intervals include one near the end of the middle Miocene (ca. 12-11 Ma), one in the early late Miocene (ca. 10-9 Ma), and one in the late late Miocene (ca. 7.2-6.2 Ma). During the early to middle part of the Pliocene (ca. 4.5-2.5 Ma), diatom productivity declined off southern California, probably associated with an interval of relative climatic warming.

Three new taxa are proposed, Annellus californicus var. hannai, n. var., Bogorovia paleacea var. elongata, n. var., and Coscinodiscus temperei var. delicata, $\mathrm{n}$, var.
\end{abstract}

\section{INTRODUCTION}

Leg 63 began in Long Beach, California, and ended in Mazatlan, Mexico (October and November, 1978). A total of eleven holes were drilled at seven sites off southern California and Baja California (Fig. 1). The richly diatomaceous sections recovered from the middle and upper Miocene of Sites 468, 469, 470, 471, and 472 are valuable reference sections for correlating middleand low-latitude diatom biostratigraphy in the eastern North Pacific, and they allow comparison of paleoceanographic data along a north to south transect within the California Current.

The middle Miocene through Quaternary diatom zonation of Koizumi $(1973,1975)$ as refined by Barron (1980) can be recognized throughout the middle- to high-latitude North Pacific. The lack of Denticulopsis kamtschatica in the upper Miocene of southern California (Barron, 1976a; Harper, 1977), however, necessitates the use of a local zonation for the upper upper Miocene to lowermost Pliocene of the southern California area. Within this interval, North Pacific Diatom Zones XI to IX of Barron (1976a) are recognizable throughout southern California (Barron, 1976b), and consequently they can be incorporated with the refined North Pacific zonation of Barron (1980) to provide a northeastern Pacific diatom zonation for Leg 63 sediments (Fig. 2). In this report, North Pacific Diatom Zones XI, X, and IX have been renamed the Thalassiosira antiqua Zone, the Nitzschia reinholdii Zone, and the Thalassiosira oestrupii Zone, respectively.

Correlation of the diatom zones and datum levels with the geologic time scale follows Barron (1980) (Fig. 2). The paleomagnetic time scale of Mankinen and Dal-

\footnotetext{
${ }^{1}$ Initial Reports of the Deep Sea Drilling Project, Volume 63.
}

rymple (1979), however, is used because it incorporates the revised potassium-argon decay constants. On the basis of the Leg 63 data, the base of Subzone D of the Denticulopsis hustedtii-Denticulopsis lauta Zone is raised slightly. In addition, the middle Miocene/upper Miocene boundary is also raised slightly following Berggren and Van Couvering (1974) and Theyer and Hammond (1974).

\section{METHODS}

Samples were taken aboard the Glomar Challenger and processed in hydrogen peroxide and hydrochloric acid according to the procedures outlined in Barron (1976a). Core-catcher samples, which were examined aboard the ship, normally were not processed. Strewn slides $(40 \times 20 \mathrm{~mm})$ were examined in entirety at $500 \times$ under the light microscope, although supplemental examination at $1250 \times$ was used to make selected identifications. Where occurrence charts were prepared, dominant and stratigraphically useful diatoms were tabulated. Selected stratigraphically useful silicoflagellates were also tabulated. The works of Schrader (1973), Burckle $(1972,1978)$, Koizumi (1975), and Barron (1976a, 1980) were consulted in selecting the stratigraphically useful taxa. Taxa were recorded as abundant if two or more specimens were present within one field of view at $500 \times(446 \mu \mathrm{m}$ diameter $)$; common if one specimen occurred within two fields of view; few if one specimen was encountered during one vertical traverse ( $22 \mathrm{~mm}$ long); and rare if specimens were sparser. Estimate of the quality of preservation was generally subjective, although poor preservation was recorded only if samples lacked specimens of Thalassiothrix longissima $100 \mu \mathrm{m}$ or more in length and if resistant diatoms such as Coscinodiscus marginatus and Actinocyclus ingens were concentrated relative to more delicate diatoms.

Description of new taxa and taxonomic notes are presented in the Appendix.

\section{RESULTS}

Table 1 summarizes the zonal assignments of diatomaceous sediments recovered during Leg 63. Samples from DSDP Site 173 off northern California, and from the Experimental Mohole Drilling Site near Site 470 were also examined, and their zonal assignments also appear in Table 1. The diatom biostratigraphy of the individual Leg 63 sites is discussed below. 


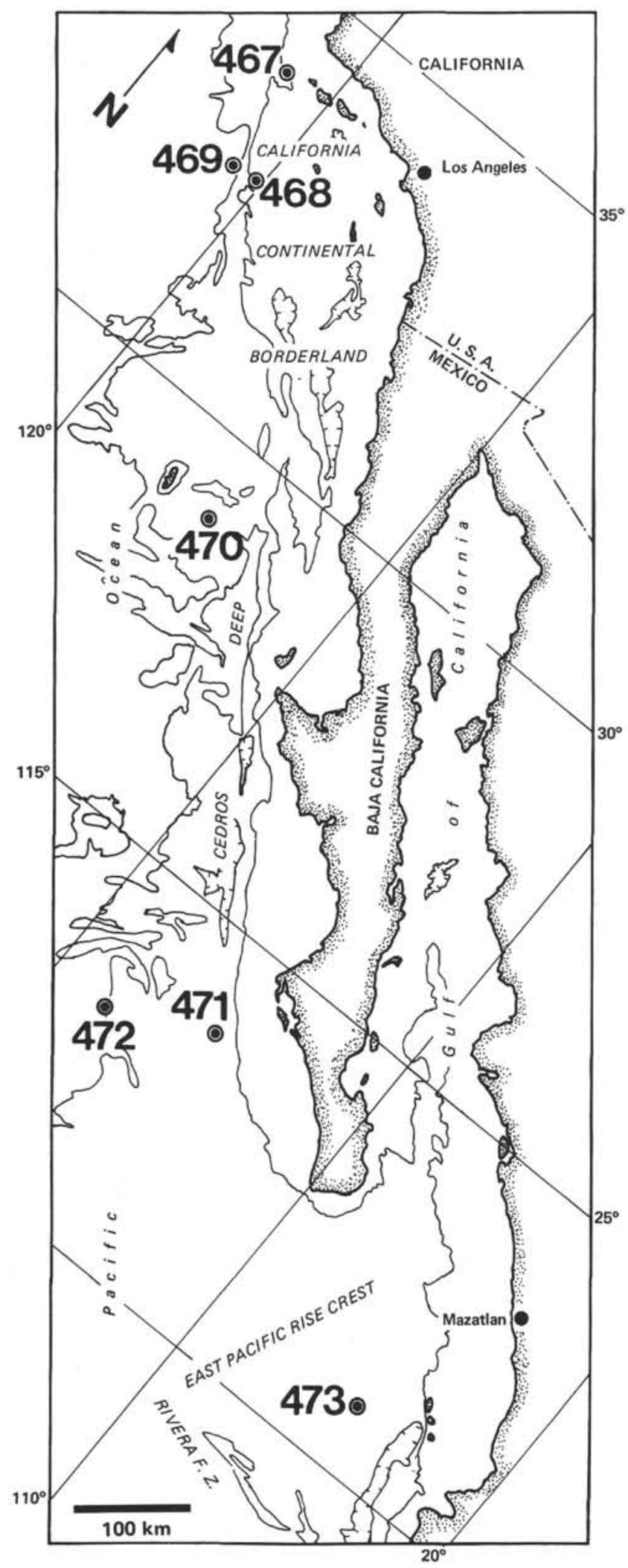

Figure 1. Location of Leg 63 sites off southern California and Baja California.

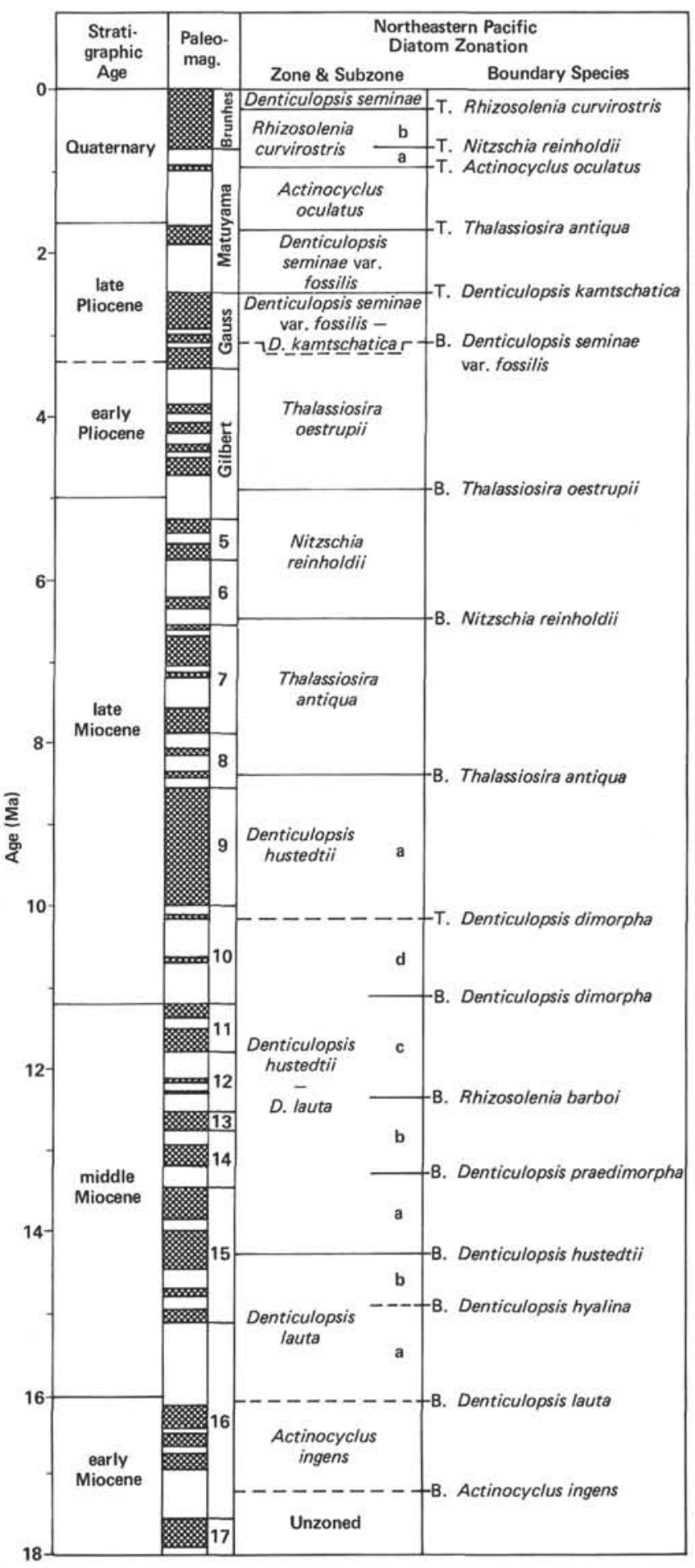

Figure 2. Northeastern Pacific diatom zonation used for Leg 63 studies. (With the exception of the Thalassiosira antiqua Zone through $T$. oestrupii Zone, the zonation is that of Barron [1980]. The $T$. antiqua Zone, Nitzchia reinholdii Zone, and $T$. oestrupii Zone are names proposed for Barron's (1976a) North Pacific Diatom Zone $\mathrm{XI}, \mathrm{X}$, and IX, respectively. B. = first occurrence; T. = last occurrence. The paleomagnetic time scale is that of Mankinen and Dalrymple [1979], which was modified from LaBrecque and others [1977].) 
Table 1. Diatom zonation of samples from DSDP Leg 63 sites, Site 173, and the Experimental Mohole Drilling Site.

\begin{tabular}{|c|c|c|c|c|c|c|c|c|c|c|c|c|}
\hline \multirow[b]{2}{*}{$\begin{array}{c}\text { Series/ } \\
\text { Subseries }\end{array}$} & \multirow{2}{*}{\multicolumn{2}{|c|}{$\begin{array}{c}\text { Diatom } \\
\text { Biostratigraphy } \\
\text { (Zone/Subzone) }\end{array}$}} & \multicolumn{9}{|c|}{ Hole or Site } & \multirow[b]{2}{*}{$\begin{array}{l}\text { Experimental Mohole } \\
\text { (EM) }\end{array}$} \\
\hline & & & 467 & 468 & $468 \mathrm{~B}$ & 469 & 470 & $470 \mathrm{~A}$ & 471 & 472 & 173 & \\
\hline \multirow{4}{*}{ Quaternary } & D. seminae & & $1, \mathrm{CC} / 3, \mathrm{CC}$ & & & & & & & & $1-1 / 2-2$ & \\
\hline & R. curvirostris & $b$ & $4, \mathrm{CC} / 6, \mathrm{CC}$ & & & & & & & & $2-2 / 3, \mathrm{CC}$ & \\
\hline & & $\mathrm{a}$ & $7 \cdot 1 / 7, \mathrm{CC}$ & & & & & & & & $4-1 / 4-5$ & \\
\hline & A. oculatus & & $8, \mathrm{CC} / 9, \mathrm{CC}$ & & & $3, \mathrm{CC} / 5-5$ & & & & & $\begin{array}{l}5-1 / 8-2, \\
8-3 ? \\
8-4 ?\end{array}$ & \\
\hline \multirow{3}{*}{ Pliocene } & $\begin{array}{l}\text { D. seminae } \\
\text { var. fossilis }\end{array}$ & & $10, \mathrm{CC} / 21-1$ & & & $5, \mathrm{CC} / 7, \mathrm{CC}$ & & & & & $8-5 / 13-1$ & \\
\hline & $\begin{array}{l}\text { D. seminae var. } \\
\text { fossilis-D. } \\
\text { kamtschatica }\end{array}$ & & "dissolved" & & & & & & $5, \mathrm{CC} / 9, \mathrm{CC}$ & & $13-4 / 14-2$ & . \\
\hline & T. oestrupii & & $38, \mathrm{CC} / 45, \mathrm{CC}$ & & & $10-5 / 11-3$ & & & & & $14-3 / 14 . C C$ & \\
\hline \multirow{4}{*}{$\begin{array}{l}\text { upper } \\
\text { Miocene }\end{array}$} & Nitzschia reinholc & & $47, \mathrm{CC} / 53, \mathrm{CC}$ & & & $11, \mathrm{CC} / 13-1$ & & & \multirow[t]{2}{*}{$10-1 / 17, \mathrm{CC}$} & & $15-2 / 15-4$ & \\
\hline & T. antiqua & & & & & $13-2 / 15-1$ & $8-2 / 9, \mathrm{CC}$ & 3-5/4,CC & & $5-1 / 6-2$ & $15, \mathrm{CC} / 17.2$ & $6-2(30-32) ? / 8-9(5-6)$ \\
\hline & D. hustedtii & a & & & & 15.2 & $10-1 / 10-2$ & $5-1 / 5, \mathrm{CC}$ & & $6-3 / 7-1^{10}$ & $17-3 / 19-3$ & $8-9(39-42) / 8-10(67-70)$ \\
\hline & \multirow{4}{*}{$\begin{array}{l}\text { D. } \\
\text { hustedtii- } \\
\text { D. lauta }\end{array}$} & d & & & $3-4^{130}$ & $15, \mathrm{CC} / 18-1$ & $11-1 / 11-5$ & & & $7-1^{77 / 8-2}$ & $19-4 / 20-3$ & $8-10(200-203) / 8-11(312-315)$ \\
\hline \multirow{5}{*}{$\begin{array}{l}\text { middle } \\
\text { Miocene }\end{array}$} & & c & & & $3, \mathrm{CC}$ & $18-3 / 19, \mathrm{CC}$ & $11, \mathrm{CC} / 14-2$ & & & $8-1 / 10-2$ & $21-1 / 21-4^{43}$ & $8-11(363-366) / 8-14(399-404)$ \\
\hline & & b & & $2, \mathrm{CC} / 3-1$ & $4-2 / 5, \mathrm{CC}$ & $20-1 / 20, \mathrm{CC}$ & $15-1 / 16-1$ & & & $11-1 / 11-3$ & $21-4^{133 / 24-4}$ & $8-15(88-91) / 8-15(578-581)$ \\
\hline & & $\mathrm{a}$ & & 3-5/5,CC & $6-3 / 10-1$ & $22-1 / 24-5$ & $16-2 / 17-3$ & & & $11-4 ? / 12-1$ & $24-5 / 27-3^{36}$ & $7-1(30-33)$ \\
\hline & \multirow[b]{2}{*}{ D. lauta } & b & & $6-1 / 9-4$ & $10, \mathrm{CC} / 14-1$ & $24-6 / 25, \mathrm{CC}$ & $17, \mathrm{CC} ?$ & & & & $27-3^{132} / 29-2^{21}$ & $7-2(0-17) ?$ \\
\hline & & a & & $10-3 / 21, \mathrm{CC}$ & $14-3 / 21, \mathrm{CC}$ & & & & & & $29-2^{145} / 30-1$ & \\
\hline
\end{tabular}

Note: Numbers assigned to zonal intervals are core and section numbers. Where several samples are assigned to a zone, the highest and lowest stratigraphic determinations are listed with a slash between. Site 173 zonation is in part after Demere (1978). Superscript numbers refer to the centimeter interval within a section.

\section{Site 467}

A single hole was drilled at Site $467\left(33^{\circ} 50.97^{\prime} \mathrm{N}\right.$, $120^{\circ} 45.47^{\prime} \mathrm{W}, 2,128 \mathrm{~m}$ water depth) to provide a reference section for the San Miguel Gap area of the outer California Continental Borderland. The hole was continuously cored to a depth of $1,041.5$ meters, where lower middle Miocene sediments were encountered.

Diatoms are generally abundant to few in the uppermost Miocene to Quaternary section recovered at Site 467. Silica diagenesis below a sub-bottom depth of 500 meters removed all but resistant, long-ranging diatoms. Figure 3 summarizes the zonal assignments and occurrence of important diatom datum levels in Hole 467.

Because of the presence of Nitzschia reinholdii without Thalassiosira oestrupii, Cores 53 through 47 (500$433 \mathrm{~m}$ ) are assigned to the uppermost Miocene Nitzschia reinholdii Zone (equivalent to North Pacific Diatom Zone X of Barron, 1976a). The last occurrence of Rouxia californica in Sample 467-49-1, $68 \mathrm{~cm}(453 \mathrm{~m})$ is a useful datum level for correlation within this zone in onshore southern California sections (Barron, 1976a). The first occurrence of Thalassiosira oestrupii in Sample 467-45, CC marks the base of the Thalassiosira oestrupii Zone (North Pacific Diatom Zone IX of Barron, 1976a) and approximates the Miocene/Pliocene boundary. The diatom assemblage of the $T$. oestrupii Zone includes Nitzschia reinholdii, Thalassiosira antiqua, T. oestrupii, and rare Denticulopsis kamtschatica and resembles assemblages in the lower parts of the Sisquoc Formation and Capistrano Formation onshore in southern California.

The interval from Core 36 through Core 23 (338-205 m) contains only reworked, fairly resistant middle and upper Miocene diatoms, which make up a minor com-

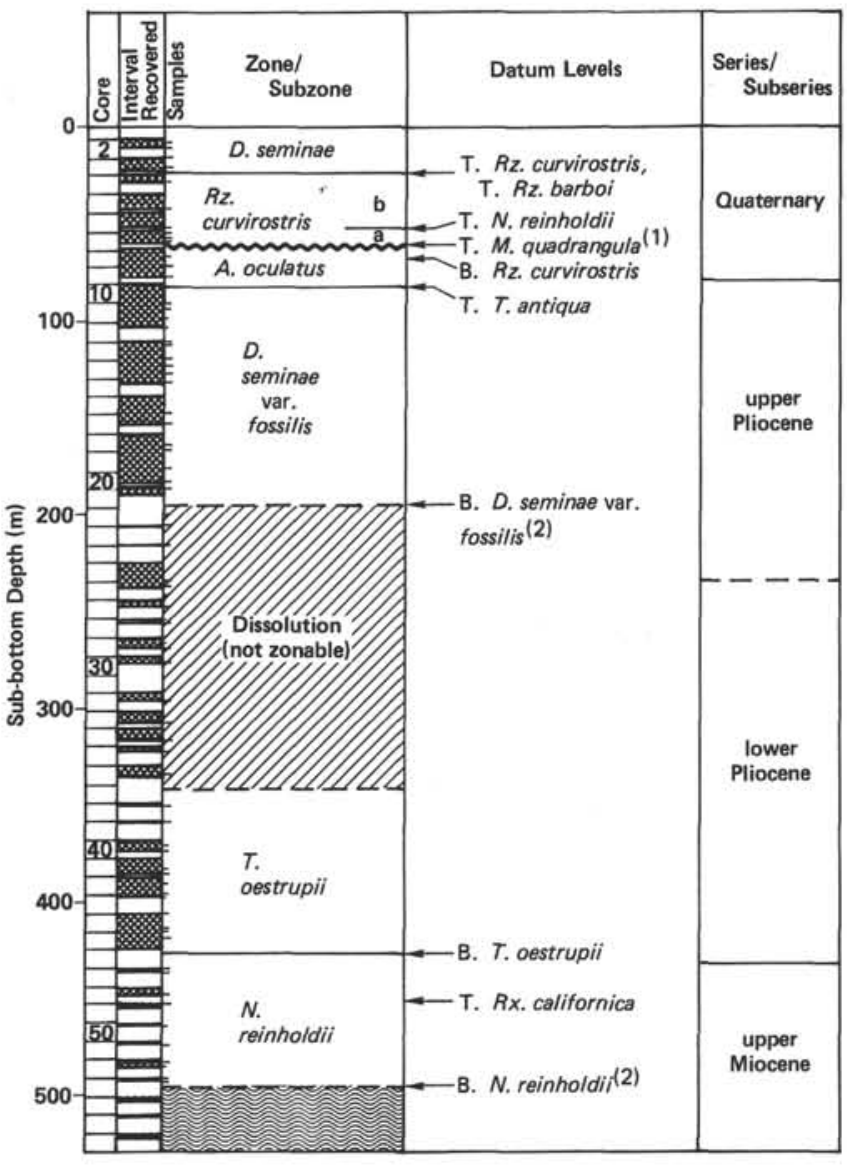

Figure 3. Stratigraphic distribution of diatom zones and datum levels at Site 467. (B. = first occurrence; T. = last occurrence. $(1)=$ silicoflagellate; (2) indicates that dissolution below obscures true datum level.) 
ponent throughout the Site 467 section. These reworked diatoms include Actinocyclus ingens, Denticulopsis hustedtii, D. lauta, Rhizosolenia barboi, Synedra jouseana, and Thalassiosira antiqua.

Cores 21 through $10(196-82 \mathrm{~m})$ are assigned to the upper Pliocene Denticulopsis seminae var. fossilis Zone on the basis of Denticulopsis seminae var. fossilis and Thalassiosira antiqua without Denticulopsis kamtschatica. Within this interval, the first occurrence of Pseudoeunotia doliolus in Sample 467-11-4, 40-42 cm (97 m) correlates with the lower part of the Olduvai Event of the Matuyama Paleomagnetic Epoch (Burckle, 1972).

Cores 9 and $8(82-63 \mathrm{~m})$ are tentatively assigned to the Actinocyclus oculatus Zone, because they lack $T$. antiqua and because Rhizosolenia curvirostris first occurs in Sample 467-8-3, 100-102 cm (67 m); Actinocyclus oculatus is not present. The last occurrence of the silicoflagellate Mesocena quadrangula in Sample 467$7, \mathrm{CC}(61 \mathrm{~m})$ correlates with the upper part of the Matuyama Paleomagnetic Epoch (Burckle, 1977) and indicates that the upper three-quarters of the $A$. oculatus Zone is removed at a hiatus at the top or within the upper part of Core 8. Calcareous nannofossils support a hiatus at approximately the same horizon (Bukry, this volume). The Rhizosolenia curvirostris Zone extends upsection from this hiatus to the last occurrence of Rhizosolenia curvirostris in Sample 467-4,CC (29 m). The last occurrence of Nitzschia reinholdii in Sample 467-7-1, 51-53 cm (54 m) marks the Subzone a/Subzone b boundary within this zone. The upper three cores of Hole 467 are assigned to the Denticulopsis seminae Zone, because Denticulopsis seminae is present without Rhizosolenia curvirostris.

\section{Site $\mathbf{4 6 8}$}

Three holes were drilled at Site 468 on the Patton Escarpment (Hole $468-32^{\circ} 37.03^{\prime} \mathrm{N}, 120^{\circ} 07.07^{\prime} \mathrm{W}$, $1,849 \mathrm{~m}$ water depth and Holes $468 \mathrm{~A}$ and $468 \mathrm{~B}-32^{\circ}$ $37.41^{\prime} \mathrm{N}, 120^{\circ} 06.55^{\prime} \mathrm{W}, 1,737 \mathrm{~m}$ water depth). Hole 468 was cored continuously to 241 meters sub-bottom depth and was abandoned due to sloughing of middle Miocene volcaniclastic sand and breccia into the hole. Hole 468A was spudded $1.2 \mathrm{~km}$ upslope, where the post-Miocene section is thicker, and was continuously cored to 35 meters before the sand line parted. The hole was respudded as Hole 468B and cored to 416 meters subbottom depth.

Nearly equivalent middle Miocene diatomaceous sections ranging from Subzone a of the Denticulopsis lauta Zone to Subzone b of the Denticulopsis hustedtii-D. lauta Zone were recovered from Holes 468 and 468B (Tables 2 and 3). The top of the diatomaceous section is slightly younger in Hole 468B, where Sample 468B-3-4, $130-131 \mathrm{~cm}(41 \mathrm{~m})$ correlates with lower upper Miocene Subzone d of the $D$. hustedtii- $D$. lauta Zone. The relatively thin post-middle Miocene section is generally characterized by sparse diatoms reworked from the middle Miocene. No hiatuses are apparent within the diatomaceous section.

\section{Site 469}

A single hole was drilled at Site $469\left(32^{\circ} 37.00^{\prime} \mathrm{N}\right.$, $120^{\circ} 32.90^{\prime} \mathrm{W}, 3,790 \mathrm{~m}$ water depth) at the foot of the Patton Escarpment. The primary objective of Site 469 was to determine the precise time that the FarallonPacific ridge intersected the trench off southern California and subduction ceased. Hole 469 was continuously cored to 454 meters sub-bottom depth, the lower 60 meters in basement rocks.

Abundant to few diatoms occur in the middle Miocene to lower Quaternary section recovered at Site 469 . Diatoms are rare in the upper Quaternary $(0-26 \mathrm{~m})$ and in the middle part of the Pliocene $(87-67 \mathrm{~m})$. Diagenesis below Core $25(235 \mathrm{~m})$ removed all but the robust, longranging species such as Coscinodiscus marginatus. The occurrences of the dominant and the stratigraphically important diatoms are shown in Table 4 . Figure 4 gives the ranges of the stratigraphically useful diatoms in the Miocene of Site 469.

A normal sequence from middle Miocene Subzone b of the Denticulopsis lauta Zone to the lower Quaternary Actinocyclus oculatus Zone occurs at Site 469, with the exception of an interval from 87 to 67 meters subbottom depth in the middle part of the Pliocene, where the diatoms cannot be zoned. This middle Pliocene interval contains only sparse, poorly preserved diatoms, including reworked middle and upper Miocene taxa, and presumably is at least partly equivalent to the Denticulopsis seminae var. fossilis-D. kamtschatica Zone, which is not represented at Site 469. A similar horizon poor in diatoms occurs at an equivalent stratigraphic interval of Hole 467; it is possible that these intervals represent a period of reduced diatom productivity possibly due to decreased upwelling during the middle part of the Pliocene.

The sequence of middle Miocene datum levels is unambiguous upsection from Core $25(235 \mathrm{~m})$ through Core $19(169 \mathrm{~m})$. Above this level, however, reworking of older diatoms characterizes the upper Miocene to Quaternary section at Site 469 (Table 4). Care must be taken in identifying datum levels above the middle Miocene, especially in the case of last occurrences. The base of the interval of reworking near the middle Miocene/upper Miocene boundary may correspond with a period of intensified tectonic activity in the nearby southern California Continental Borderland. Crouch (personal communication, 1978) reports a widespread upper middle Miocene unconformity in the borderland, and the transition from the thick diatomaceous middle Miocene section to the thin post-middle Miocene section at nearby Site 468 on the Patton Ridge is approximately correlative. Within this interval at Site 469, Subzone c of the Denticulopsis hustedtii-D. lauta Zone (Sample $469-19, \mathrm{CC}[170 \mathrm{~m}]$ to Sample 469-18-3, 89-90 cm [163 m]) may be truncated at its top by a hiatus on the basis of the ranges of Denticulopsis punctata var. hustedtii, Rhizosolenia praebarboi, and Hemidiscus cuneiformis (Fig. 4). 
Table 2. Stratigraphic occurrence of selected diatoms and silicoflagellates in Hole 468.

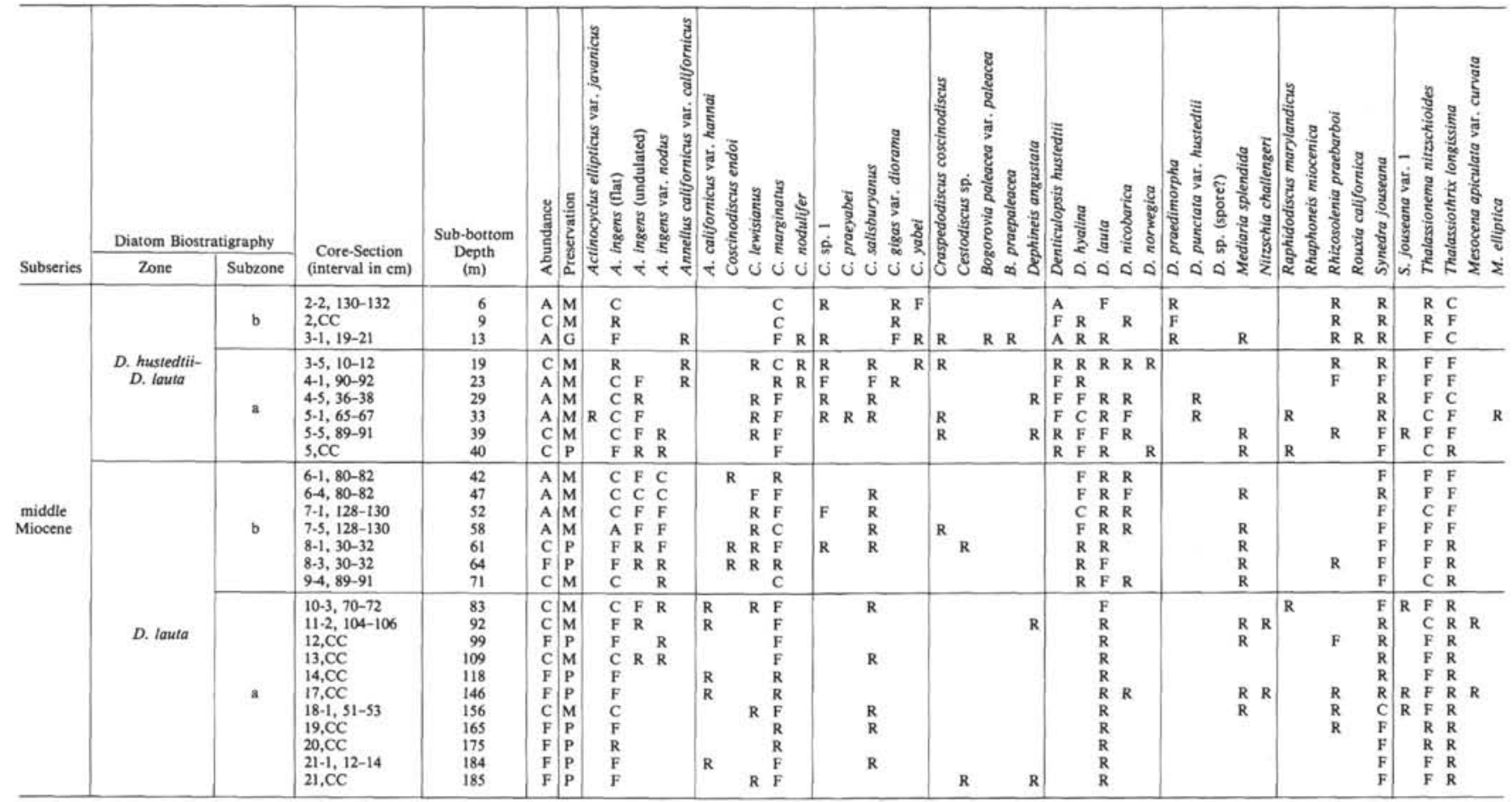

Note: $\mathrm{A}=$ abundant, $\mathrm{C}=$ common, $\mathrm{F}=$ few, $\mathrm{R}=$ rare, $\mathrm{R}=$ reworked. Preservation: $\mathrm{G}=\mathrm{good}, \mathrm{M}=$ moderate, $\mathrm{P}=$ poor.

Table 3. Stratigraphic occurrence of selected diatoms and silicoflagellates in Hole $468 \mathrm{~B}{ }^{\mathrm{a}}$

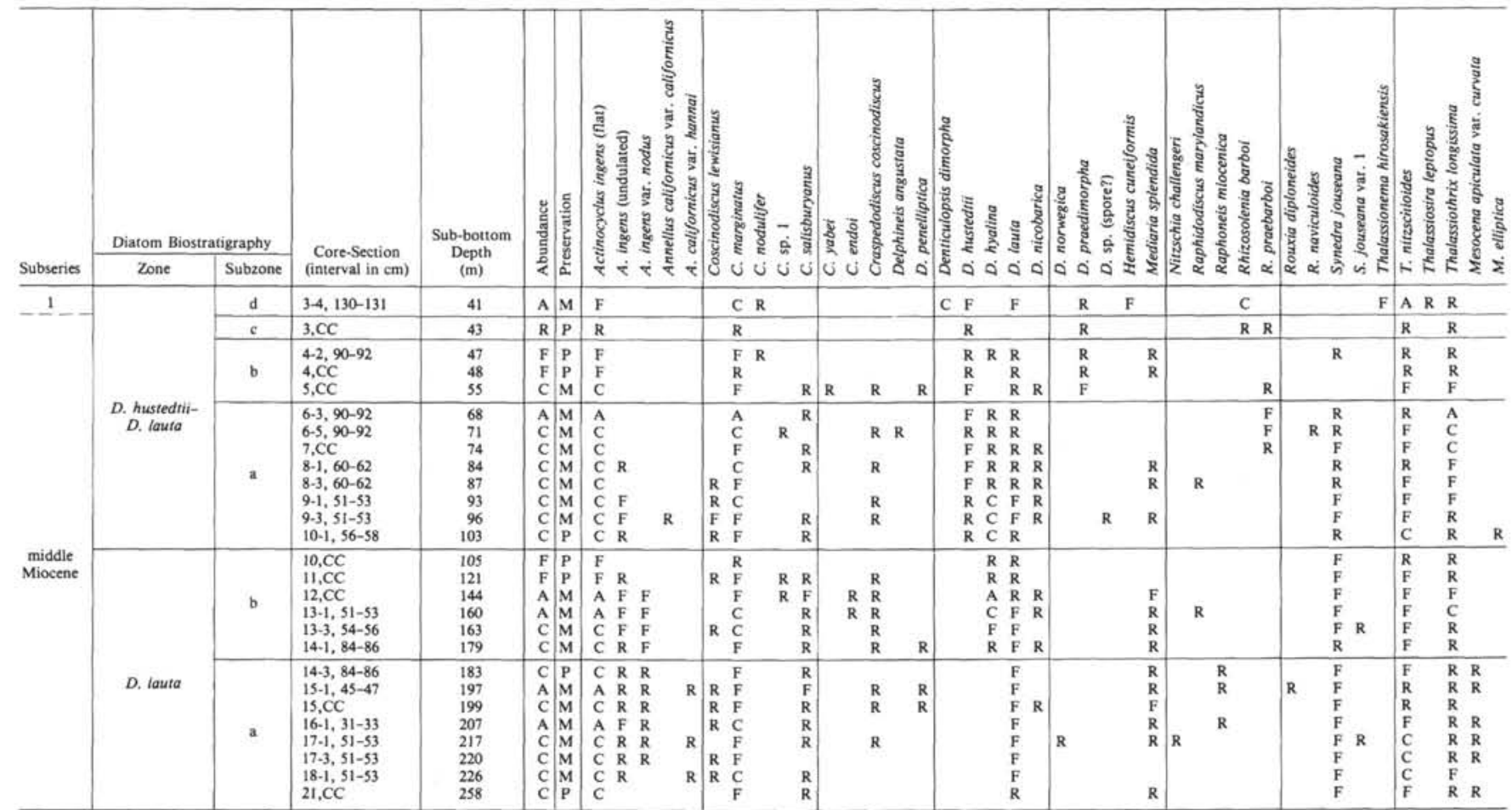

a Abbreviations are explained in Table 2.1. = upper Miocene. 
Table 4. Stratigraphic occurrences of selected diatoms in Hole 469. ${ }^{\text {a }}$

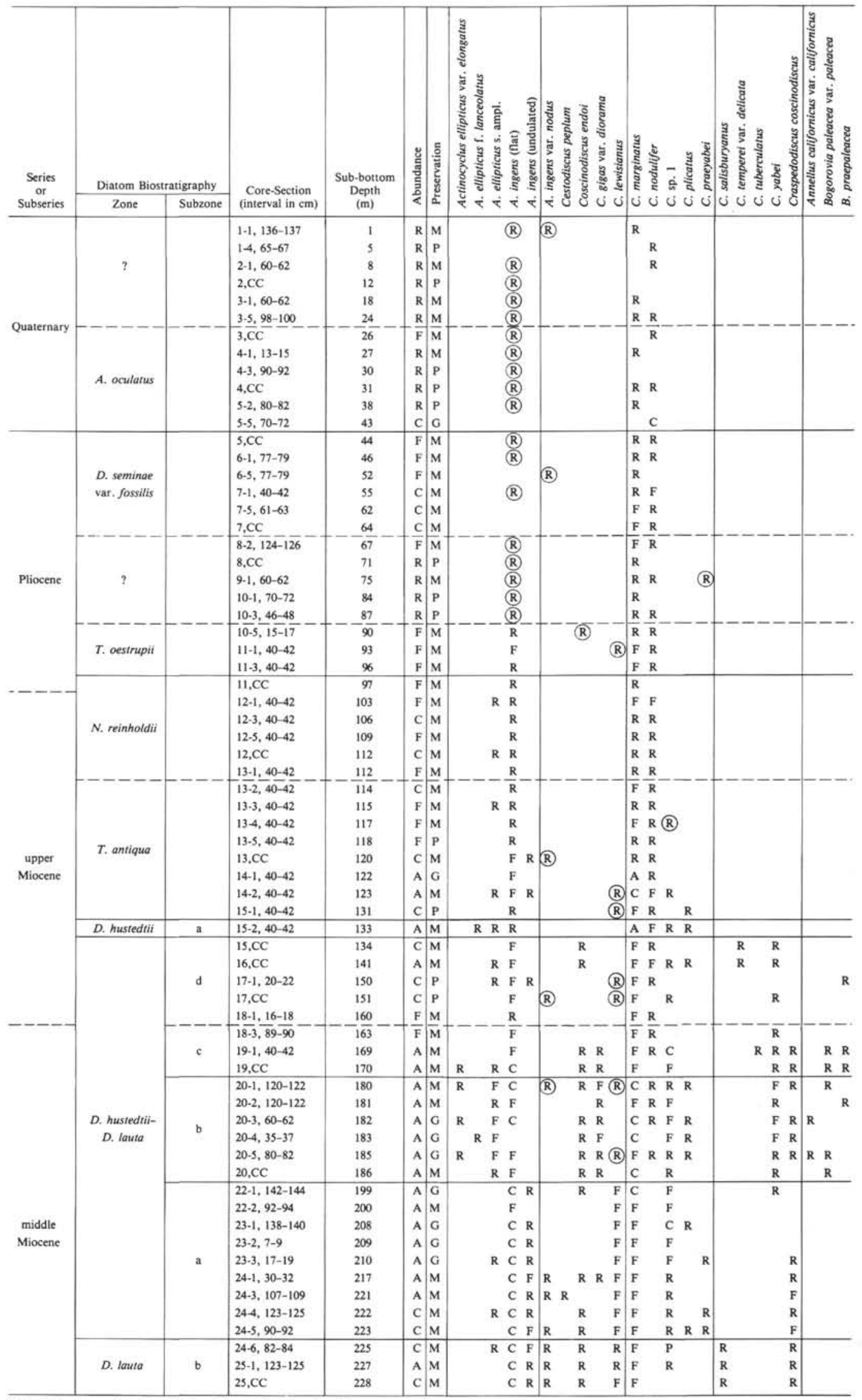

${ }^{\text {a }}$ See Table 2 for explanation of abbreviations. Also, ${ }^{*}=$ downhole contamination. 
Table 4. (Continued).

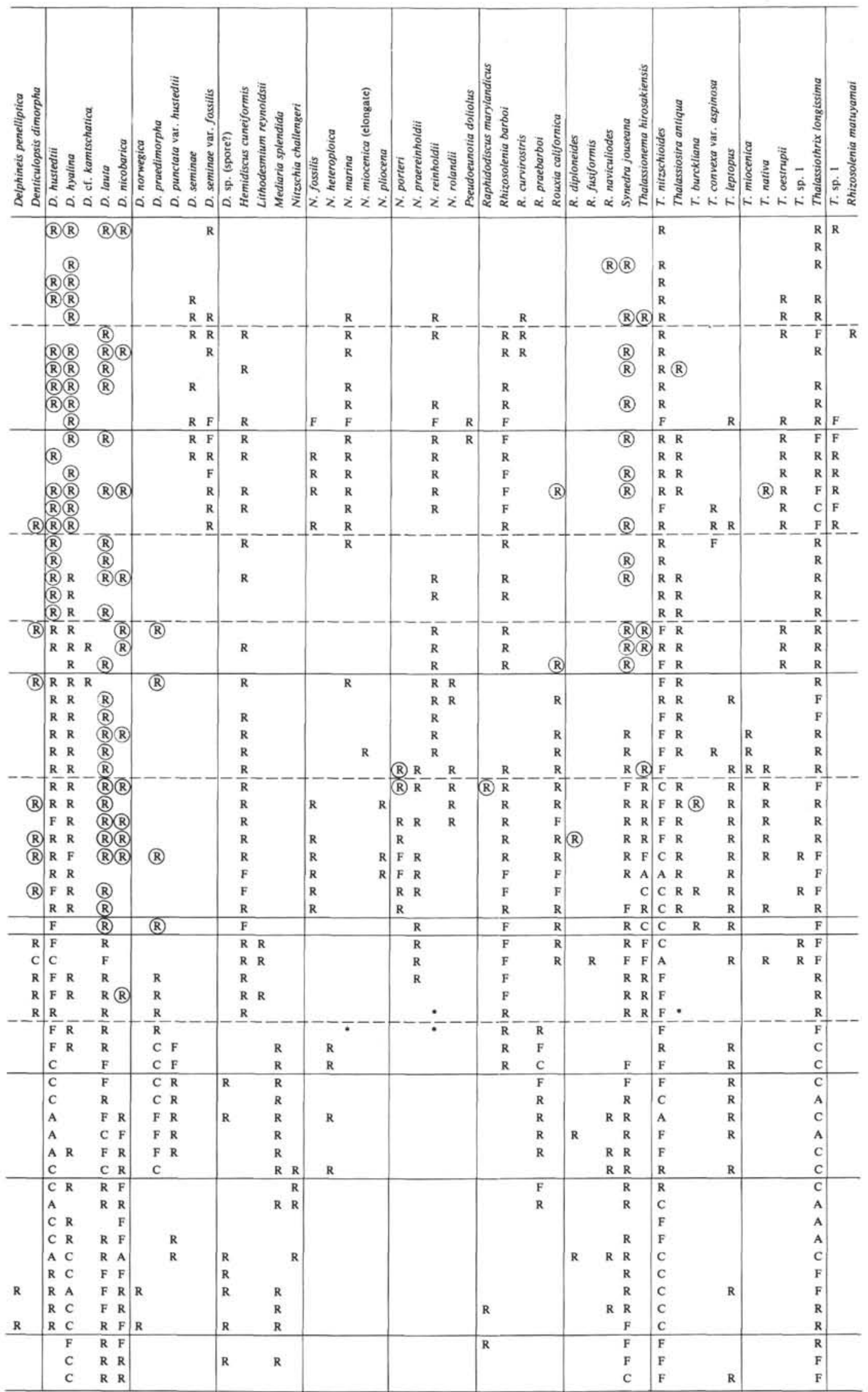




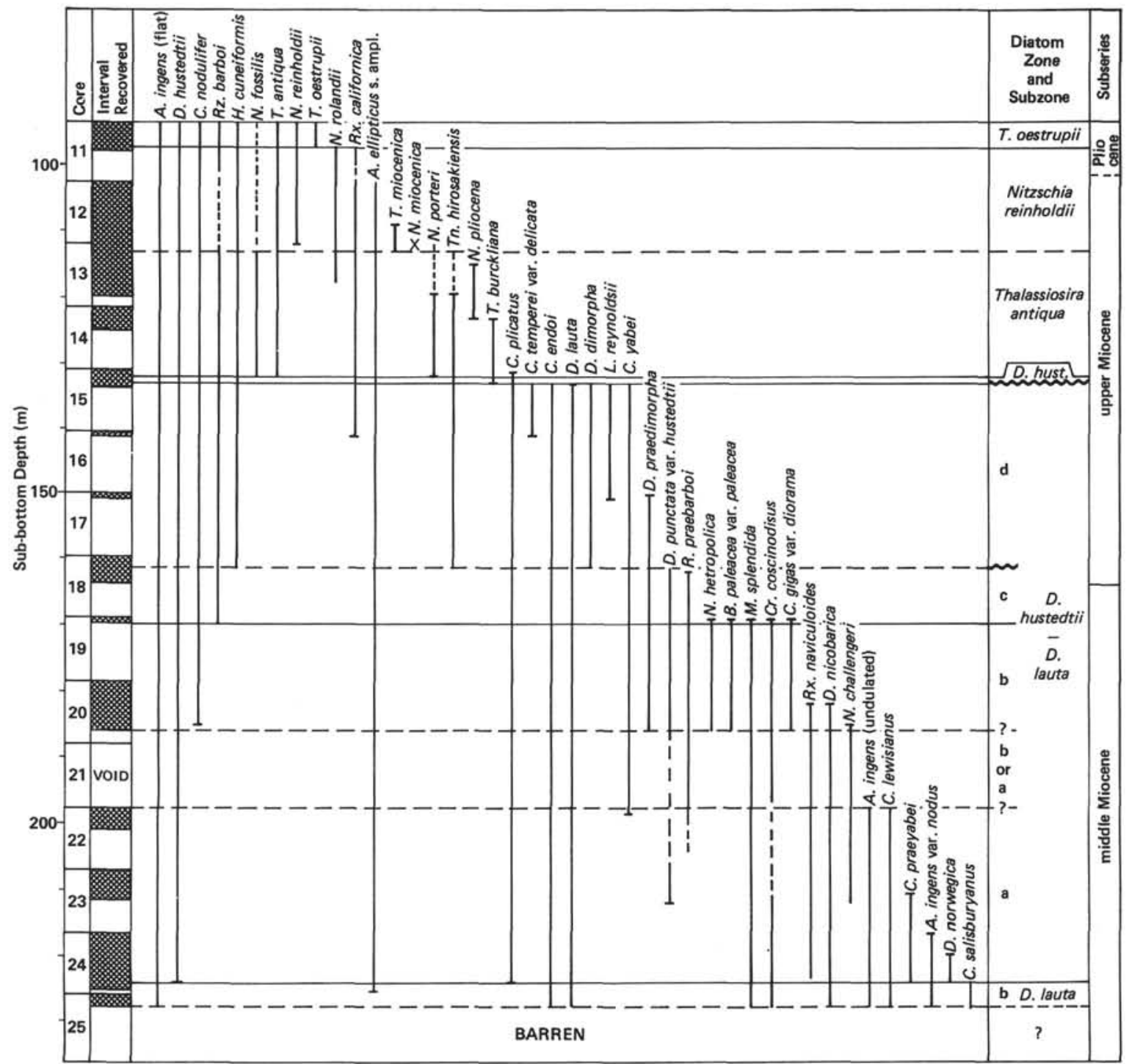

Figure 4. Stratigraphic ranges of selected Miocene diatoms at Site 469. (Note hiatus in Core 15 and possible hiatus in Core 18.)

The last occurrences of Coscinodiscus temperei var. delicata n. var., C. endoi, Denticulopsis dimorpha, D. lauta, and Lithodesmium reynoldsii in Sample 46915 , CC $(134 \mathrm{~m})$ overlain by the first occurrence of Thalassiosira burckliana in Sample 469-15-2, 40-42 cm (133 $\mathrm{m})$ argue for the presence of a hiatus at the top of the $D$. hustedtii-D. lauta Zone, which removes all but the uppermost part of overlying Subzone a of the $D$. hustedtii Zone (Fig. 4). Glauconitic sediment in Section 2 of Core 15 is supportive of this hiatus.

Rather than at the first occurrence of Nitzschia reinholdii, the base of the Nitzschia reinholdii Zone is tentatively placed at the first occurrence of Thalassiosira miocenica in Sample 469-13-1, 40-42 cm (112 m). Contrary to the relationships in Hole 469 (Fig. 4), Thalassiosira miocenica is expected to occur first above the first occurrence of Nitzschia reinholdii. This expectation is based on studies onshore in southern California (Barron, 1976a), in the middle-latitude western North Pacific (Barron, 1980), and in the tropical Pacific (Burckle,
1978). The absence of Nitzschia reinholdii in Core 13 of Hole 469 below the first occurrence of Nitzschia reinholdii may reflect either a hiatus or ecologic exclusion. Bukry (this volume) suspects a hiatus between Cores 13 and 14 because of the absence of the Discoaster berggrenii Subzone (calcareous nannofossil).

The interval above the last occurrence of Thalassiosira antiqua in Sample 469-5, CC (44 m) through Sample 469-3, CC (26 m) is assigned to the Actinocyclus oculatus Zone, even though Actinocyclus oculatus is not present; Rhizosolenia matuyamai occurs in Sample 469$3, \mathrm{CC}$ and indicates equivalence with the upper part of the A. oculatus Zone (Burckle et al., 1978). Diatoms in the overlying upper Quaternary of Site 469 are sparse and cannot be zoned.

\section{Site 470}

Site 470, east of Guadalupe Island off Baja California, was proposed to continuously core the sediment section only partially recovered in 1961 at the Experi- 
mental Mohole Drilling Site. Site 470 is located $8 \mathrm{~km}$ south-southwest of the old Mohole site (at $28^{\circ} 54.46^{\prime} \mathrm{N}$, $117^{\circ} 31.11^{\prime} \mathrm{W}, 3,549 \mathrm{~m}$ water depth). Hole 470 was continuously cored to basalt at $163 \mathrm{~m}$ sub-bottom depth. Hole $470 \mathrm{~A}$ was drilled to resample critical sediment intervals from 47.5 to 95 meters and from 161.6 meters to the top of the basalt and to continuously core in basalt to 216 meters sub-bottom depth.

Abundant to few diatoms are present in the middle to upper Miocene section recovered at Site 470. Diatoms decrease markedly in abundance upsection at a subbottom depth of 68 meters in Hole 470 (about $70 \mathrm{~m}$ in Hole 470A); diagenesis below 160 meters results in severe diatom dissolution in sediment immediately overlying the basement. Preservation in the diatomaceous section is generally good to moderate, with the exception of Core 470-13, where poorly preserved diatoms are present. Post-Miocene sediment contains rare and nonage-diagnostic diatoms, with the exception of Sample 470-2,CC (17 m), where sparse Quaternary diatoms including Rhizosolenia curvirostris and Pseudoeunotia doliolus occur.

Table 5 gives the occurrences of dominant diatoms and stratigraphically important diatoms and silicoflagellates in the Miocene of Holes 470 and 470A. The ranges of stratigraphically useful taxa are summarized in Figure 5. Sample 470-17,CC (156 m), at the base of the diatomaceous section, is tentatively assigned to Subzone b of the Denticulopsis lauta Zone; a normal sequence of zones occurs upsection through the Denticulopsis hustedtii-D. lauta Zone to the Thalassiosira antiqua Zone. The presence of Thalassionema hirosakiensis in Samples 470-8-2, 12-14 cm (68 m) and 470A$3-5,40-42 \mathrm{~cm}(73 \mathrm{~m})$ above the last occurrence of Thalassiosira burckliana suggests correlation of the top of the diatomaceous section with the middle part of the $\mathrm{Pa}$ leomagnetic Epoch 7 (Barron, 1980). On the basis of radiolarians and calcareous nannofossils, the Miocene/ Pliocene boundary is placed about 5 meters above the top of the diatomaceous section (Wolfart, this volume; Bukry, this volume). The brevity of the overlying upper Miocene section and the abrupt decrease in the abundance of diatoms suggest the possibility of a hiatus at this horizon (see Site 470 report, this volume).

A second hiatus is suggested at about 85 meters subbottom depth by the absence of assemblages characteristic of the upper part of Subzone a of the Denticulopsis hustedtii Zone in both Holes 470 and $470 \mathrm{~A}$. This hiatus, however, is more speculative, because it occurs between cores (i.e., Cores 9 and 10 of Hole 470; Cores 4 and 5 of Hole 470A).

Schrader (1974) assigned the diatoms of the nearby Experimental Mohole section to North Pacific Diatom Zones XXIV to X. In terms of the Leg 63 diatom zonation, this is equivalent to Subzone a of the Denticulopsis lauta Zone to the Nitzschia reinholdii Zone (Barron, 1980). The author's examination of samples from the Experimental Mohole section, however, confirms the same sequence encountered at Site 470-Subzone b of the $D$. lauta Zone to the Thalassiosira antiqua Zone (Table 1). Correlation by diatoms of the Experimental
Mohole section with the section recovered at Site 470 is shown in Figure 6. Stratigraphic horizons in the two sections are at roughly the same sub-bottom depths. Dymond's (1966) potassium-argon dates of $11.7 \pm 0.6 \mathrm{Ma}$ for Sample EM-8-13, $133 \mathrm{~cm}$ and $12.6 \pm 0.4 \mathrm{Ma}$ for Sample EM-8-15, $89 \mathrm{~cm}$ (corrected by Dalrymple's [1979] tables) are in good agreement with the absolute ages predicted by diatoms.

Kanaya's (1971) correlation of the California benthic foraminiferal stages with the Experimental Mohole section is generally supported. Baldauf and Barron (1980) approximate the Mohnian/Luisian Stage boundary with the top of the Denticulopsis lauta Zone. Barron (1976a) correlates the lower Mohnian/upper Mohnian boundary with the top of the Denticulopsis hustedtii-D. lauta Zone at upper Newport Bay in southern California. The base of the Delmontian, as defined by the base of the benthic foraminiferal Bolivina obliqua Zone, however, lies within the Nitzschia reinholdii Zone (Barron, 1976b) and, consequently, occurs above the diatomaceous section of the Experimental Mohole section.

\section{Site 471}

A single hole was drilled at Site $471\left(23^{\circ} 28.93^{\prime} \mathrm{N}\right.$, $112^{\circ} 29.78^{\prime} \mathrm{W}, 3,101 \mathrm{~m}$ water depth) in a sedimentary wedge west of the foot of the continental slope off Baja California to provide a reference section for the area. Hole 471 was continuously cored to 823 meters subbottom depth, the lower 82 meters of which were in diabase and presumed to be basement.

Common to abundant upper Miocene to lower Pliocene diatoms are present in Cores 17 to $5(161-47 \mathrm{~m})$ of Hole 471. Nearshore diatoms, such as Actinocyclus ehrenbergii, Rhaphoneis spp., and Thalassiosira spp., are present in Core 1 and are not age diagnostic. Diagenesis below Core 17 removes all but non-age-diagnostic diatoms such as Coscinodiscus marginatus.

Figure 7 gives the occurrences of stratigraphically important diatoms and selected silicoflagellates in Hole 471. Relatively common benthic and neritic planktonic diatoms and a mixture of temperate and tropical oceanic diatoms characterize the assemblages. The presence of Lithodesmium asketogonium and the absence of Nitzschia porteri, $N$. reinholdii, and Thalassionema hirosakiensis suggest that the base of the diatomaceous section correlates with the upper part of Paleomagnetic Epoch 7 (Barron, 1980; Burckle, 1972). The absence of Nitzschia miocenica below Sample 471-16-2, 20-22 (144 $\mathrm{m})$ presumably is the result of ecological exclusion, because Core 17 contains relatively common Coscinodiscus marginatus, a cooler water diatom. The first occurrences of the elongate form of Nitzschia miocenica and of Thalassiosira miocenica in Core 12 suggest correlation with the middle and upper part of Paleomagnetic Epoch 6, respectively, according to Burckle (1978; personal communication, 1978). Similarly, the work of Burckle (1978; personal communication, 1978) in the tropical Pacific suggests that the last occurrence of Nitzschia miocenica in Sample 471-10,CC (95 m) correlates with the top of the reversed event of Paleomagnetic Epoch 5, the last occurrence of Thalassiosira miocenica 


\section{J. A. BARRON}

Table 5. Stratigraphic occurrences of selected diatoms and silicoflagellates in Holes 470 and $470 \mathrm{~A} .{ }^{\mathrm{a}}$

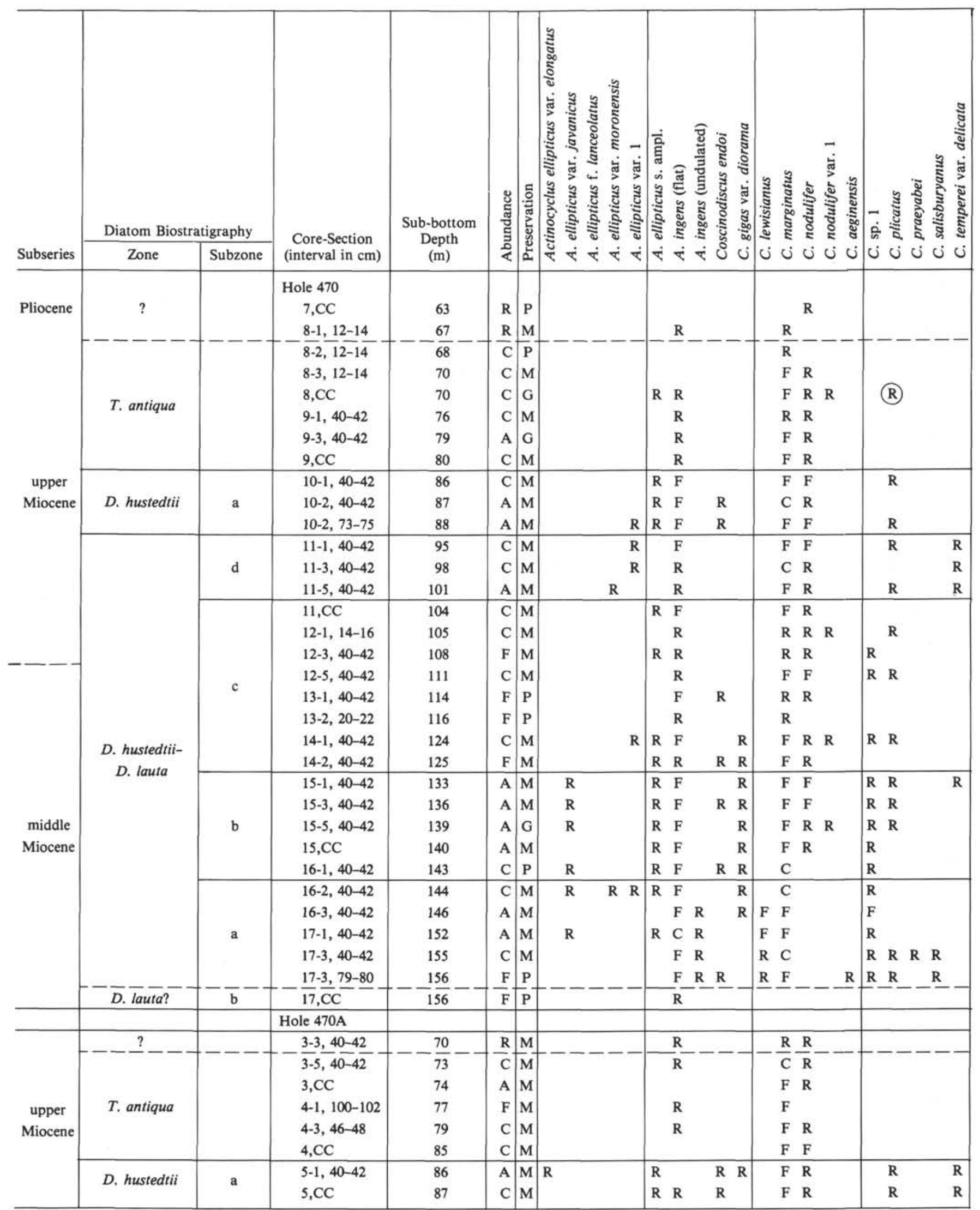

a Abbreviations are explained in Table 2. 
Table 5. (Continued).

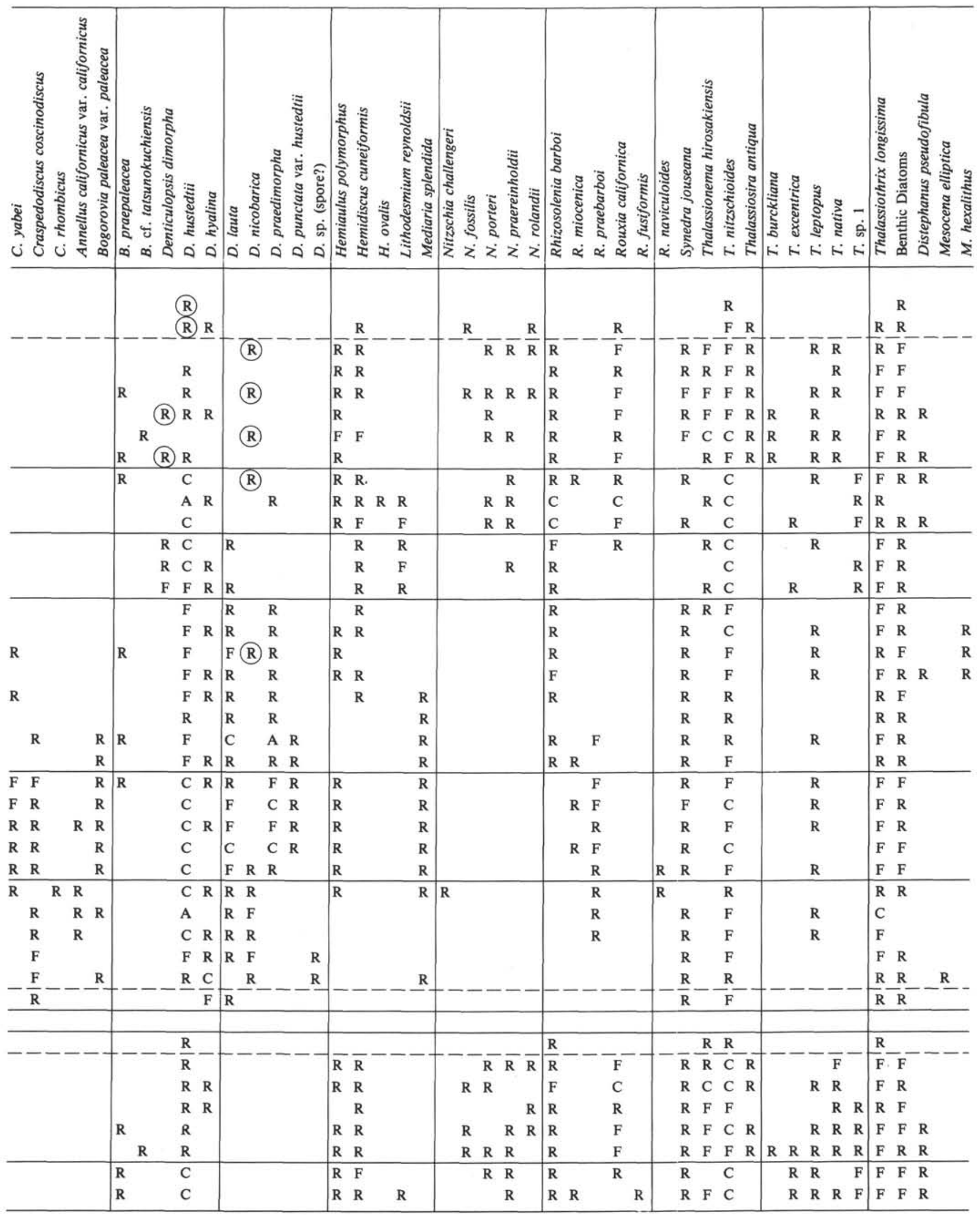




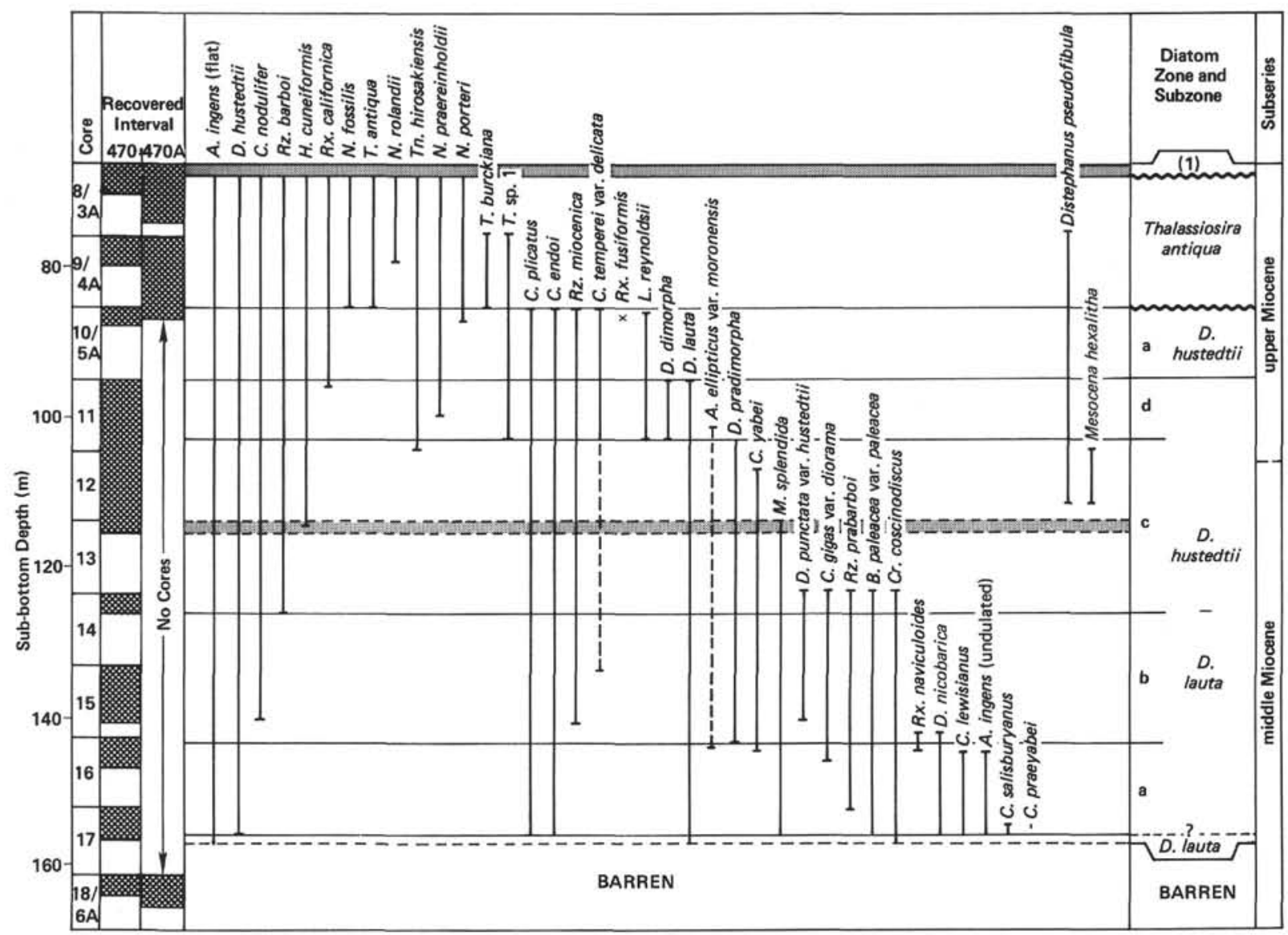

Figure 5. Stratigraphic ranges of selected diatoms and silicoflagellates in the Miocene at Site 470. (Shaded areas represent pronounced diatom dissolution [other than that due to silica diagenesis]. Note that a possible hiatus at $85 \mathrm{~m}$ sub-bottom depth removes the upper half of Subzone a of the D. hustedtii Zone. (1) indicates that this interval was identified as upper Miocene by Bukry [this volume].)

in Sample 471-10-1, 20-22 cm (86 m) approximates the Miocene/Pliocene boundary in the lower Gilbert Epoch, and that the first occurrence of Coscinodiscus nodulifer var. cyclopus in Sample 471-8-1, 120-122 cm (68) correlates with the lower $\mathrm{c}$ event of the Gilbert Epoch. Placement of the Miocene/Pliocene boundary is supported by the presence of the silicoflagellate Dictyocha neonautica var. cocosensis in Sample 471-10-1, 20$22 \mathrm{~cm}$ and by the first occurrence of Thalassiosira oestrupii in Sample 471-9-1, 58-60 cm (77 m).

\section{Site 472}

Site $472\left(23^{\circ} 00.35^{\prime} \mathrm{N}, 113^{\circ} 59.71^{\prime} \mathrm{W}, 3,831 \mathrm{~m}\right.$ water depth) was proposed to obtain an upper Neogene record of pelagic sedimentation unaffected by terrigenous sediment sources such as those affecting Site 471 . Hole 472 was continuously cored to 138 meters sub-bottom depth through 112 meters of sediment and 26 meters of fresh pillow basalt. Only $20 \mathrm{~cm}$ of basalt were recovered in Hole $472 \mathrm{~A}$, which was spudded to take a second downhole temperature measurement.

Diatoms are abundant to few in the middle to upper Miocene of Site 472. Diagenesis below 100 meters subbottom depth essentially removed all diatoms from the sediment immediately overlying the basement, and diatoms decrease dramatically in abundance upsection at 35 meters sub-bottom depth. Only rare and poorly preserved diatoms are present in overlying Cores 4 and 3. Bukry (personal communication, 1978) compared the silicoflagellates of Cores 4 and 3 with upper upper Miocene assemblages at nearby Site 471 .

Table 6 shows the occurrences of dominant and stratigraphically useful diatoms and the silicoflagellate Distephanus pseudofibula in the diatomaceous section at Site 472 . The ranges of the stratigraphically useful diatoms in this interval are depicted in Figure 8. The Miocene assemblages of Site 472 contain a mixture of lowand middle- to high-latitude diatoms, and both cool-water and warm-water Miocene datum levels can be identified. The last occurrences of Bogorovia paleacea var. paleacea and Coscinodiscus yabei are relatively lower (older) at Site 472 than they are in the eastern equatorial Pacific, whereas common Denticulopsis hustedtii ranges relatively higher (younger) (compare Burckle, 1978). In addition, Coscinodiscus vetustissimus var. javanica, a stratigraphically useful low-latitude diatom, is absent at Site 472. Otherwise the low-latitude datum levels proposed by Burckle (1978) occur in the same sequence as they do in eastern equatorial Pacific Holes 77B and 158 (J. A. Barron, unpublished data). A normal sequence of 


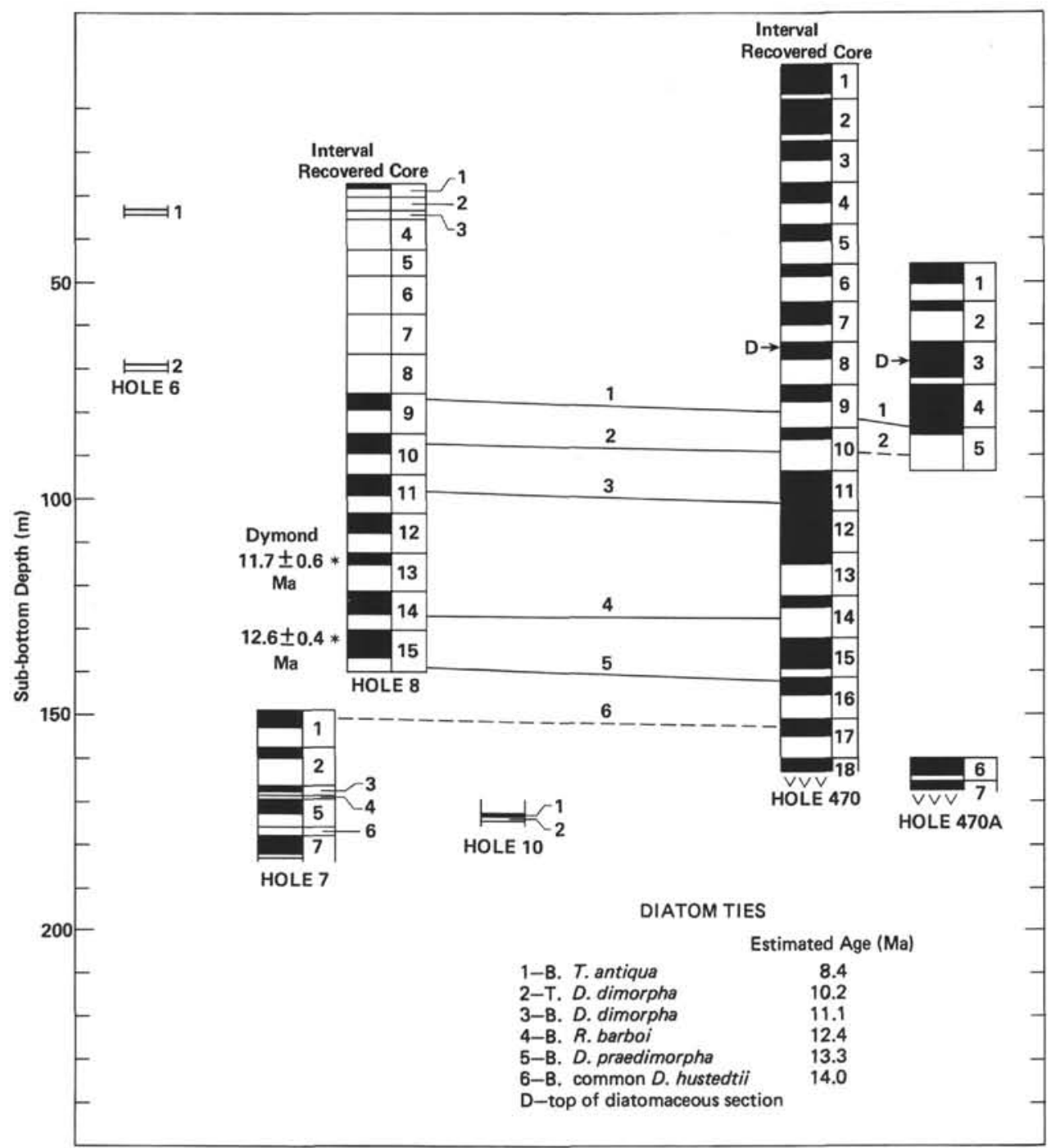

Figure 6. Correlation by diatoms of the section recovered at Site 470 with section recovered at the nearby Experimental Mohole Site. (Stratigraphic horizons at Site 470 are at sub-bottom depths approximately equal to those at the Experimental Mohole Site. Note that the K-Ar dates of Dymond [1966] - * = corrected by Dalrymple's [1979] tables - are in good agreement with the dates estimated by the diatom stratigraphy. $\mathrm{B} .=$ first occurrence and $\mathrm{T}$. = last occurrence.)

the middle- to high-latitude diatom zones from Subzone a of the Denticulopsis hustedtii-D. lauta Zone to the Thalassiosira antiqua Zone can also be recognized (Table 6) at Site 472 , along with the associated datum levels.

Three intervals of poor diatom preservation occur within the diatomaceous section at Site 472 (Fig. 8). Poor preservation at the base of the section is probably associated with silica diagenesis. A prominent dissolution interval occurs in Cores 10 and 9 (84-72 m), and a shorter dissolution interval is present in Core 6 (47-49 $\mathrm{m})$. The dramatic decrease in abundance and preservation above Core $5(35 \mathrm{~m})$ probably reflects migration of Site 472 into the region of lessened diatom productivity associated with the central North Pacific. Thalassionema hirosakiensis and Nitzschia porteri above the last occurrence of Thalassiosira burckliana correlate the top of the richly diatomaceous section at Site 472 with the middle part of Paleomagnetic Epoch 7 (Burckle, 1978; Barron, in press). The diatomaceous section at nearby Site 471, which begins in upper Epoch 7, consequently forms a composite section with Site $\mathbf{4 7 2}$ for the upper Miocene of the area off southern Baja California.

\section{Site 473}

Site $473\left(20^{\circ} 57.92^{\prime} \mathrm{N}, 107^{\circ} 03.81^{\prime} \mathrm{W}, 3,249 \mathrm{~m}\right.$ water depth), on the Rivera plate south of the Tres Marias Islands, was continuously cored to obtain an upper Neogene reference section at the mouth of the Gulf of California and to investigate the possibility of the presence of oceanic crust at the mouth of the gulf prior to 4 Ma. Basalt was encountered at 248 meters sub-bottom depth below upper upper Miocene sediments, and 41 meters of basalt were cored.

The upper Miocene to Quaternary section recovered at Site 473 is largely hemipelagic, and diatoms are 


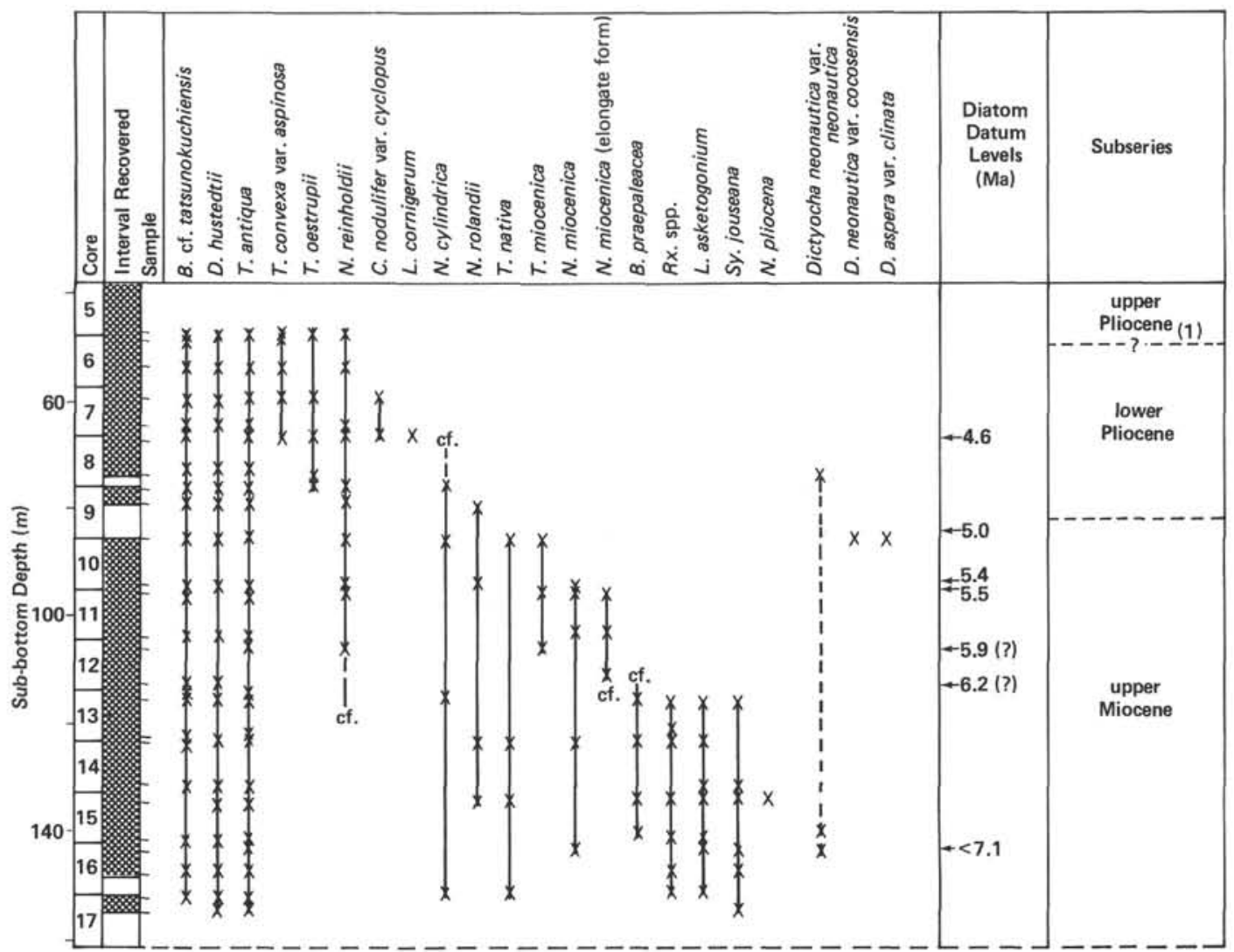

Figure 7. Stratigraphic ranges of selected diatoms and silicoflagellates in the upper Miocene and lower Pliocene at Site 471. (Ages of datum levels are after Burckle [1978; personal communication, 1979]. (1) indicates that the interval was identified as upper Pliocene by Bukry [this volume]).

generally sparse. In the lower parts of Hole 473 (247$181 \mathrm{~m})$, diatoms are absent or represented by pyritized fragments of Coscinodiscus spp. A well-preserved lower Pliocene diatom assemblage of the low-latitude Nitzschia jouseae Zone of Burckle (1972) occurs in Sample 473-20-6, 52-54 cm (192 m); Nitzschia jouseae, $N$. reinholdii, Thalassiosira convexa var. aspinosa, and $T$. nativa are among the diatoms present. Pliocene diatoms, including Bogorovia spp., $N$. reinholdii, $T$. convexa var. aspinosa, and $T$. oestrupii are sparse in Cores 19 through 16 (171-133 m). Cores 15 through 5 (133-29 $\mathrm{m})$ are barren of diatoms or contain only sparse diatoms. Because of the presence of Pseudoeunotia doliolus and Nitzschia marina and the absence of $N$. reinholdii, the few to rare diatoms in Cores 4 through 1 $(29-0 \mathrm{~m})$ are assigned to the upper Quaternary low-latitude Pseudoeunotia doliolus Zone of Burckle (1977).

\section{DISCUSSION \\ ZONATION}

Study of the diatom biostratigraphy of Leg 63 sediments adds significantly to the refinement of middle-latitude middle Miocene to Quaternary diatom biostratigraphy in the eastern North Pacific. Specifically, the interval from the base of the Denticulopsis hustedtiiD. lauta Zone to the Thalassiosira antiqua Zone is well represented along a north to south transect from Site 469 to Site $\mathbf{4 7 2}$. Numerous diatom datum levels within this interval allow precise correlation be- tween the Leg 63 sites and with Site 173 to the north (Table 7). In the following section, the middle Miocene through Quaternary diatom zones of the northeastern Pacific are discussed incorporating the results of Leg 63 .

\section{Denticulopsis lauta Zone}

Author. Koizumi, 1973 (top); Barron, 1980 (base).

Base. First occurrence of Denticulopsis lauta s. str.

Top. First occurrence of Denticulopsis hustedtii.

Subzones. The first occurrence of Denticulopsis hyalina defines the top of Subzone a and the base of Subzone b (Barron, in press).

Correlation. Barron (in press) correlates the top of the zone with the middle part of Paleomagnetic Epoch 15 and approximates the base of the zone with the base of the middle Miocene. Baldauf and Barron (1980) note that the top of the zone approximates the top of the Sphenolithus heteromorphus Zone (calcareous nannofossil) of Bukry (1973). Relationships at Sites $468,469,470$, and 472 confirm this correlation (Bukry, this volume).

Remarks. At Site 468, Annellus californicus var. hannai is restricted to Subzone a. This range is supported by the author's unpublished studies of U.S. Geological Survey dart-core material collected in the southern California Continental Borderland. Rhaphoneis miocenica and the silicoflagellate Mesocena apiculata var. curvata do not range above Subzone a at Site 468 , as was reported by Barron (1980) at Site 438 off Japan.

\section{Denticulopsis hustedtii-Denticulopsis lauta Zone}

Author. Koizumi (1975); top modified by Barron (in 1980).

Base. Coincident with the top of the $D$. lauta Zone.

Top. Last occurrence of Denticulopsis dimorpha.

Subzones. Barron (1980) defined four subzones. The bases of these subzones are defined as follows: Subzone a-coincident with the base of the $D$. hustedtii-D. lauta Zone; Subzone b-first occurrence of 
Denticulopsis praedimorpha; Subzone c-first occurrence of Rhizosolenia barboi; and Subzone d-first occurrence of Denticulopsis dimorpha.

Correlation. Barron (1980) correlated the base of the zone with the middle part of Paleomagnetic Epoch 15, the base of the Subzone b with the lower reversed event of Epoch 14, the base of Subzone c with lower Epoch 12, the base of Subzone d with the uppermost part of Epoch 11, and the top of the zone with the uppermost part of the Epoch 10. At Sites 470 and 472, the first occurrence of $D$. dimorpha (the base of Subzone d) corresponds closely with the last occurrence of Actinocyclus ellipticus var. moronensis, a datum level that Burckle (1978) correlates with the lowermost part of Paleomagnetic Epoch 10. The base of Subzone $d$ is therefore raised accordingly to the lowermost part of Epoch 10 (Fig. 2).

Remarks. Leg 63 studies show that numerous datum levels within the $D$. hustedtii- $D$. lauta Zone are valuable for long-range correlation. The first occurrence of Coscinodiscus plicatus s. ampl. is a secondary marker for the base of the zone, and the first common occurrence of Denticulopsis hustedtii, within Subzone a, is an event recognizable throughout the middle- to high-latitude North Pacific. Coscinodiscus lewisianus last occurs near the first occurrence of Coscinodiscus yabei just below the top of the Subzone a. In Leg 63 sediments Annellus californicus var. californicus is restricted to the upper part of Subzone a and the lower part of Subzone b. Subzone b contains the last occurrence of $D$. nicobarica near its base and the first occurrence of Coscinodiscus temperei var. delicata near its top. The last occurrence of Craspedodiscus coscinodiscus, D. punctata var. hustedtii, Bogorovia paleacea var. paleacea, and Coscinodiscus gigas var. diorama all fall within the lower part of Subzone c. The latter two last occurrences appear to be environmentally caused, because $C$. gigas var. diorama ranges into the upper Miocene onshore in southern California (Barron, 1975) and B. paleacea var. paleacea ranges into the upper Miocene in the tropical Pacific (Burckle, 1978). The last occurrences of Rhizosolenia praebarboi and Mediaria splendida are also stratigraphically useful datum levels within Subzone a.

In contrast to relationships at Site 438 off Japan, in Leg 63 material, Hemidiscus cuneiformis first occurs within the middle part of Subzone $\mathrm{c}$ rather than near its base. At eastern equatorial Pacific Sites 77 and 158, H. cuneiformis overlaps slightly with the ranges of Craspedodiscus coscinodiscus and Denticulopsis punctata var. hustedtii (J. A. Barron, unpublished data), whereas there is no such overlap in Leg 63 material. It is therefore likely that the first occurrence of $H$. cuneiformis in Leg 63 sediments represents a migrational event rather than an evolutionary appearance.

The first occurrence of Lithodesmium reynoldsii approximates the base of Subzone d of the $D$. hustedtii- $D$. lauta Zone, and the last occurrence of Denticulopsis lauta corresponds closely with the top of the zone. As observed by Barron (1980), the last occurrence of $D$. dimorpha is normally easier to identify than the last occurrence of D. lauta, Koizumi's (1975) marker for the top of the zone. D. dimorpha has a more distinctive morphology, and D. lauta has a greater tendency to be reworked upsection, especially in the southern California Continental Borderland.

\section{Denticulopsis hustedtii Zone-Subzone a}

Author. Barron (1980).

Base. Coincident with the base of the $D$. hustedtii Zone and the top of the D. hustedtii-D. lauta Zone.

Top. Last occurrence of Coscinodiscus yabei.

Correlation. Barron (1980) correlates the base of this subzone with the uppermost part of Paleomagnetic Epoch 10 and the top with the middle reversed event of Epoch 8.

Remarks. In the middle-latitude eastern North Pacific, the top of this subzone is recognized by the first occurrence of Thalassiosira anti$q u a$, the secondary marker for its top at Site 438 off Japan (Barron, 1980). The last occurrence of Coscinodiscus yabei in the middlelatitude eastern North Pacific is stratigraphically lower than it is in the tropical Pacific or at Site 438 (Barron, 1976a; Fig. 4, 5, 8, this chapter).

The last occurrences of Coscinodiscus temperei var. delicata and Lithodesmium reynoldsii are consistently just above the base of Subzone a. North of about $28^{\circ} \mathrm{N}$ (Site 470 and north), the last occurrence of C. endoi is a useful datum level in the lower part of the subzone; however, C. endoi ranges higher (younger) at Site 472 and in the eastern equatorial Pacific (J. A. Barron, unpublished data). Within Subzone a, Denticulopsis hustedtii decreases upsection in abundance from common to rare throughout the middle- and high-latitude North Pacific. Nitzschia fossilis and Thalassiosira burckliana make their first appearance near the top of Subzone a.

\section{Thalassiosira antiqua Zone}

Author. Name proposed here for Barron's (1976a) North Pacific Diatom Zone XI.

Base. First occurrence of Thalassiosira antiqua.

Top. First occurrence of Nitzschia reinholdii.

Correlation. Barron (1980) correlates the first occurrence of $T$. antiqua, the base of the zone, with the middle part of Paleomagnetic Epoch 8 on the basis of extrapolation. Burckle (1978) places the first occurrence of Nitzschia reinholdii, the top of the zone, in the lowermost part of Paleomagnetic Epoch 6.

Remarks. The absence of Denticulopsis kamtschatica in the upper Miocene of the middle-latitude eastern North Pacific necessitates the substitution of local zones, for the upper upper Miocene to lowermost Pliocene (Barron, 1976a). The Thalassiosira antiqua Zone closely approximates Barron's (1980) Subzone b of the Denticulopsis hustedtii Zone, which represents the interval from the last occurrence of Coscinodiscus yabei to the first occurrence of $D$. kamtschatica s. str.

The last occurrences of Thalassiosira burckliana, Thalassionema hirosakiensis, and Nitzschia porteri are useful datum levels in the middle-latitude North Pacific within the Thalassiosira antiqua Zone, as is the last occurrence of the silicoflagellate Distephanus pseudofibula. At Site 469 Nitzschia pliocena is restricted to the zone, a range similar to that at Site 438 off Japan (Barron, 1980).

\section{Nitzschia reinholdii Zone}

Author. Name proposed here for Barron's (1976a) North Pacific Diatom Zone X.

Base. Coincident with the top of the Thalassiosira antiqua Zone.

Top. First occurrence of Thalassiosira oestrupii.

Correlation. The base of this zone correlates with the lowermost part of Paleomagnetic Epoch 6 (Burckle, 1978). The top of the zone correlates with the lower reversed event of the Gilbert Epoch just above the Miocene/Pliocene boundary (Burckle and Opdyke, 1977).

Remarks. This zone is a local zone proposed for California because of the absence of Denticulopsis kamtschatica in the upper Miocene. As North Pacific Diatom Zone X, it has been recognized throughout southern California (Barron, 1976b).

Useful datum levels within this zone include the last occurrence of Rouxia californica and the restricted range of Thalassiosira miocenica. In California, T. miocenica and Nitzschia miocenica occur together in a restricted horizon just below the Miocene/Pliocene boundary (Burckle and Opdyke, 1977; Addicott et al., 1978).

At Site 469 , the first occurrence of Nitzschia reinholdii follows upsection the first occurrence of $T$. miocenica. This unusual relationship indicates either a hiatus or ecological exclusion of $N$. reinholdii in the lower part of its normal range.

\section{Thalassiosira oestrupii Zone}

Author. Barron (1976a) in part as North Pacific Diatom Zone IX.

Base. Coincident with the top of the Nitzschia reinholdii Zone.

Top. Tentatively placed here at the first occurrence of Denticulopsis seminae var. fossilis.

Correlation. The base of the zone correlates with the lower reversed event of the Gilbert Paleomagnetic Epoch just above the Miocene/Pliocene boundary (Burckle and Opdyke, 1977; Barron, 1980).

Remarks. The top of this zone has not been observed because of the upsection disappearance of diatoms onshore in southern California (Barron, 1976a) as well as the upsection scarcity of in situ diatoms at Sites 467 and 469 . On the basis of the sediment accumulation curve for Site 469 (see site chapter, this volume), the actual observed diatomaceous record expressed within the zone appears to be relatively short, possibly less than 500,000 years.

Denticulopsis seminae var. fossilis-Denticulopsis kamtschatica Zone

Author. Koizumi (1973).

Base. First occurrence of Denticulopsis seminae var. fossilis. 
Table 6. Stratigraphic occurrences of selected diatoms and the silicoflagellate Distephanus pseudofibula in Hole $472 .^{\text {a }}$

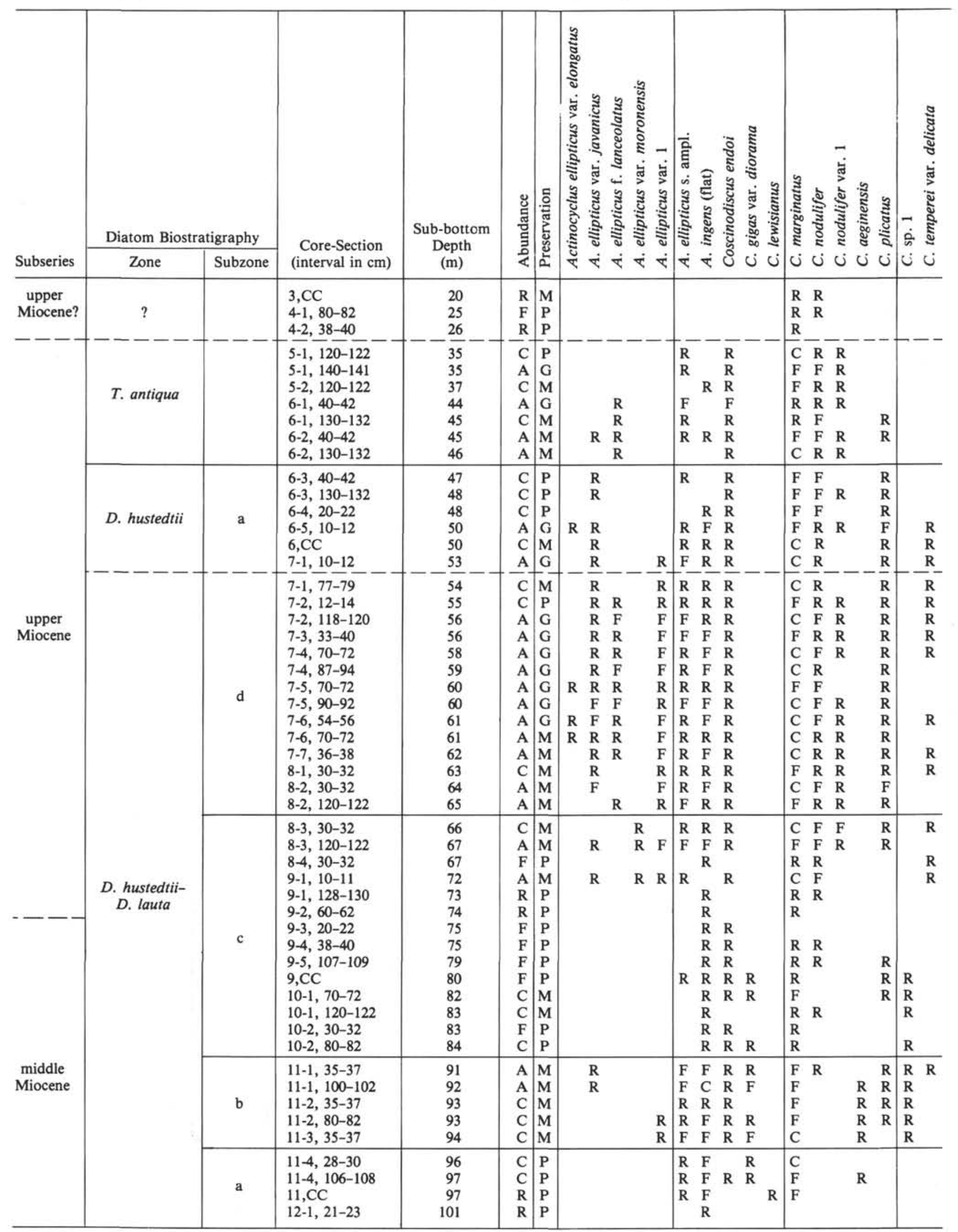

\footnotetext{
a Abbreviations are explained in Table 2.
} 


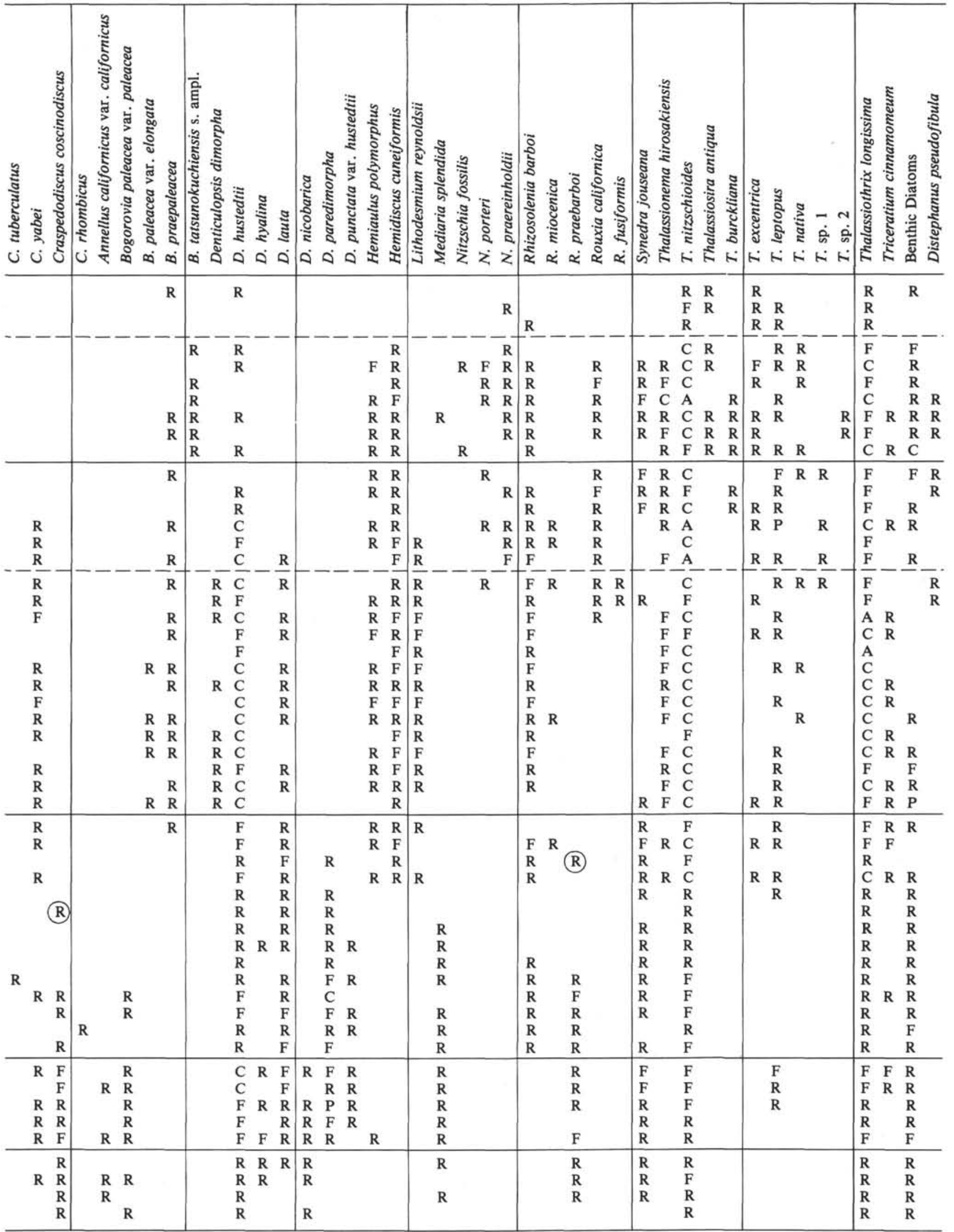




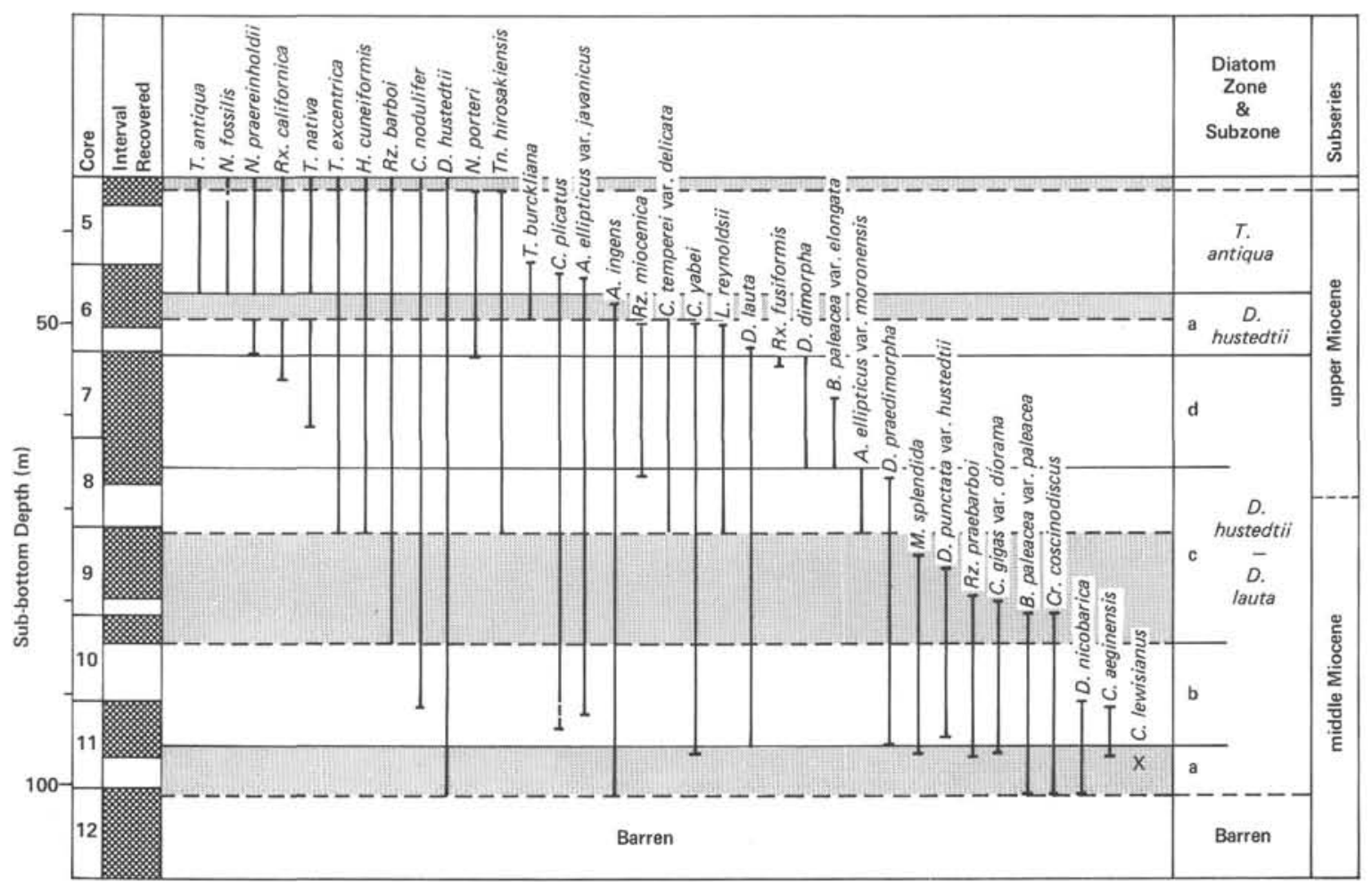

Figure 8. Stratigraphic ranges of selected diatoms in the Miocene at Site 472. (Shaded areas represent pronounced diatom dissolution. Dissolution in Core 11 is probably due to diagenesis.)

Table 7. Stratigraphic occurrence of selected middle Miocene and upper Miocene diatom datum levels at Sites 469, 470, 472, and 173.

\begin{tabular}{|c|c|c|c|c|c|}
\hline & & \multicolumn{4}{|c|}{$\begin{array}{c}\text { Sub-bottom Depth (m) } \\
\text { Site }\end{array}$} \\
\hline & & 173 & 469 & 470 & 472 \\
\hline $\mathrm{T}$ & Thalassionema hirosakiensis & 135 & $120 ?$ & 68 & 35 \\
\hline $\mathrm{T}$ & Thalassiosira burckliana & 135 & 123 & 76 & 44 \\
\hline $\mathrm{T}$ & Coscinodiscus plicatus & 151 & 131 & 86 & 45 \\
\hline B & Thalassiosira antiqua & 149 & 131 & 85 & 46 \\
\hline B & Nitzschia fossilis & 152 & 131 & 85 & 46 \\
\hline B & Thalassiosira burckliana & 153 & 133 & 85 & 48 \\
\hline $\mathrm{T}$ & Coscinodiscus temperei var. delicata & 166 & 134 & 86 & 50 \\
\hline $\mathrm{T}$ & Lithodesmium reynoldsii & 169 & 134 & 87 & 50 \\
\hline $\mathrm{T}$ & Denticulopsis lauta & 172 & $134 ?$ & 95 & 53 \\
\hline $\mathrm{T}$ & Denticulopsis dimorpha & 172 & 134 & 95 & 54 \\
\hline B & Denticulopsis dimorpha & 181 & 160 & 101 & 65 \\
\hline B & Lithodesmium reynoldsii & 187 & 151 & 101 & 72 \\
\hline B & Hemidiscus cuneiformis & 187 & 160 & 114 & 72 \\
\hline $\mathrm{T}$ & Denticulopsis punctata var. hustedtii & 188 & 169 & 124 & 75 \\
\hline $\mathrm{T}$ & Coscinodiscus gigas var. diorama & 189 & 169 & 124 & 80 \\
\hline $\mathrm{T}$ & Bogorovia paleacea var. paleacea & 189 & 169 & 124 & 82 \\
\hline $\mathrm{T}$ & Craspedodiscus coscinodiscus & 188 & 169 & 124 & 82 \\
\hline B & Rhizosolenia barboi & 191 & 170 & 125 & 84 \\
\hline B & Coscinodiscus temperei var. delicata & 197 & ? & 133 & 91 \\
\hline $\mathrm{T}$ & Denticulopsis nicobarica & 215 & 182 & 143 & 93 ? \\
\hline B & Denticulopsis praedimorpha & 220 & $186^{*}$ & 143 & 94 \\
\hline B & Coscinodiscus yabei & 228 & 199 & 144 & 97 \\
\hline $\mathrm{T}$ & Coscinodiscus lewisianus & 230 & $199^{*}$ & 146 & 97 \\
\hline B & common Denticulopsis hustedtii & 237 & 210 & 152 & $?$ \\
\hline B & Coscinodiscus plicatus & 246 & 223 & 156 & $?$ \\
\hline B & Denticulopsis hustedtii & 246 & 223 & 156 & $?$ \\
\hline
\end{tabular}

Note: $\mathrm{B}=$ first occurrence; $\mathrm{T}=$ last occurrence; $*$ indicates datum level is affected by the absence of sediment in Core 469-21; ? indicates datum level is uncertain because of diagenesis.
Top. Last occurrence of Denticulopsis kamtschatica.

Correlation. In the middle-latitude North Pacific, the base of this zone correlates with the middle part of the Gauss Paleomagnetic Epoch (about 3.1 Ma) based on extrapolation by Barron (1980). The top of this zone correlates with the top of the Gauss Epoch (Burckle and Opdyke, 1977).

Remarks. Although this zone is present at Site 173 (Table 1), it is not represented in Leg 63 sediments and has not been observed in the southern California area by the author (unpublished data). At Sites 467 and 469 it is represented by a diatom dissolution interval, where only reworked upper and middle Miocene diatoms are present.

\section{Denticulopsis seminae var. fossilis Zone}

Author. Koizumi (1975).

Base. Coincident with the top of the $D$. seminae var. fossilis- $D$. kamtschatica Zone.

Top. Last occurrence of Thalassiosira antiqua.

Correlation. The zone correlates with the interval from the top of the Gauss Paleomagnetic Epoch to within the Olduvai Event of the Matuyama Epoch (Burckle and Opdyke, 1977).

Remarks. At Sites 467 and 469 , the base of this zone was not observed due to dissolution.

The last occurrence of Thalassiosira convexa var. aspinosa falls in the lower part of the zone, and the first occurrences of $D$. seminae and Pseudoeunotia doliolus lie near its top.

\section{Actinocyclus oculatus Zone}

Author. Koizumi (1973).

Base. Coincident with the top of the $D$. seminae var. fossilis Zone.

Top. Last occurrence of Actinocyclus oculatus.

Correlation. This zone correlates with the interval from within the Olduvai Event to within the Jaramillo Event of the Matuyama Paleomagnetic Epoch (Burckle and Opdyke, 1977).

Remarks. Actinocyclus oculatus is absent from Leg 63 material, and the top of this zone is recognized by secondary criteria at Sites 467 and 469 (i.e., the last occurrence of the silicoflagellate Mesocena 
quadrangula [Site 467] and the last occurrence of Rhizosolenia matuyamai [Site 469]).

Rhizosolenia curvirostris first occurs in the lower part of the zone.

Rhizosolenia curvirostris Zone

Author. Koizumi (1973).

Base. Coincident with the top of the Actinocyclus oculatus Zone. Top. Last occurrence of Rhizosolenia curvirostris.

Subzones. The last occurrence of Nitzschia reinholdii defines the top of Subzone a and the base of Subzone b (Barron, 1980).

Correlation. The base of the zone correlates within the Jaramillo Event of the Matuyama Paleomagentic Epoch. The base of Subzone b lies in the lower part of the Brunhes Paleomagnetic Epoch, and the top of the zone lies in the upper part of the Brunhes Epoch (about 0.25 Ma) (Burckle and Opdyke, 1977).

Remarks. The last occurrences of the silicoflagellate Mesocena quadrangula, within the lower part of the zone within Subzone a (Barron, in press), is used to approximate the base of the zone at Site 467. The last occurrence of Rhizosolenia barboi corresponds with the last occurrence of $R$. curvirostris at Site 467.

\section{Denticulopsis seminae Zone}

Author. Koizumi (1973). Zone.

Base. Coincident with the top of the Rhizosolenia curvirostris

Top. Recent.

Correlation. This zone extends from about $0.25 \mathrm{Ma}$ to the Holocene (Koizumi, 1973; Burckle and Opdyke, 1977).

Remarks. This zone is only recognizable at Site 467.

\section{MIOCENE HIATUSES}

Three intervals of pronounced hiatus development occur in the middle and upper Miocene sections recovered at Leg 63 sites and at Site 173 to the north.

At Site 173, a latest middle Miocene hiatus (ca. 12-11 Ma) removes the upper part of Subzone c of the Denticulopsis hustedtii-D. lauta Zone at 186 meters subbottom depth. An equivalent hiatus is probably present at about 160 meters sub-bottom depth at Site 469 ; however, it is partially obscured by reworking and minor downhole contamination. The missing interval, which is represented by that part of Subzone c above the last occurrence of Craspedodiscus coscinodiscus, is present at Sites 470 and 472 , where it largely corresponds with an interval of increased diatom dissolution (Cores 470-13 and 472-9). Moore and others (1978) note that hiatuses of this age are widespread especially in the easterly equatorial Pacific, and they suggest that erosion by Antarctic bottom water during a growth phase of the Antarctic ice sheet is responsible. Growth of Antarctic ice during this period (12-11 Ma) is also supported by Keigwin's (1979) $\delta^{18} \mathrm{O}$ data on benthic foraminifers at Site 158 in the eastern equatorial Pacific. Diatom dissolution within this interval at Sites 470 and $\mathbf{4 7 2}$ may be due to the resulting generation of highly oxygenated "young" bottom waters, which tend to be more corrosive to the test of diatoms, silicoflagellates, and radiolarians than older bottom waters (Heath, 1974).

A second interval of hiatus development occurs in the early late Miocene (ca. 10-9 Ma) within Subzone a of the Denticulopsis hustedtii Zone. A hiatus corresponding to this interval of time is present at Site 469 (133 m) and Site $472(49 \mathrm{~m})$ and may also be present at Site 470 at about 85 meters sub-bottom depth. The missing inter- val is represented by Core $18(157.5-167 \mathrm{~m})$ at Site 173 in which Bukry (this volume) records his coolest silicoflagellate Miocene paleotemperatures. In the middlelatitude central and western North Pacific, Keller (1980) notes the presence of an approximately equivalent early late Miocene hiatus associated with the extinction of the planktonic foraminifer Globoquadrina dehiscens, and she concludes that it corresponds with climatic cooling. Onshore in southern California, Barron (1973) also records pronounced climatic cooling during this interval within the $D$. hustedtii Zone. Similarly, Haq's comprehensive study of Miocene Atlantic calcareous nannofossils (personal communication, 1979) shows a pronounced migration toward the equator of high-latitude assemblages between 10 and $9 \mathrm{Ma}$. Although Keigwin's (1979) isotopic data show only a gradual positive enrichment in $\delta^{18} \mathrm{O}$ during this interval, Woodruff, Savin, and Douglas' data at Site 289 in the western North Pacific (personal communication, 1979) show a rather sharp increase in the $\delta^{18} \mathrm{O}$ of benthic foraminifers at a seemingly equivalent horizon (middle part of planktonic foraminiferal Zone N16). Increased flow of Antarctic bottom water during a period of high-latitude cooling is, therefore, postulated as the mechanism (through erosion) for formation of the hiatuses of 10-9 Ma.

The upper half of Paleomagnetic Epoch 7 and the lower half of Epoch 6 (ca. 7.2-6.2 Ma) correspond to a third interval of widespread hiatus development. Hiatuses of varying duration, corresponding with this interval of time, are widespread throughout the middle-and high-latitude North Pacific (Barron, 1980; Keller, 1980). A late late Miocene hiatus at Site 470 (68 m subbottom depth) separates richly diatomaceous sediment assigned to the middle part of Epoch 7 from overlying uppermost Miocene nondiatomaceous sediment. At Site 472 , richly diatomaceous sediment equivalent to the middle part of Epoch 7 passes abruptly upsection into poorly diatomaceous sediment at 35 meters sub-bottom depth. This transition probably represents movement of Site 472 out of the region of productive coastal waters; however, its abrupt nature and the very poor stratigraphic control available for the overlying sediments suggests the possibility of a hiatus. At Site 469, Bukry (this volume) notes the absence of the calcareous nannofossil Discoaster berggrenii Subzone and infers a possible hiatus at 121 meters sub-bottom depth. Diatoms immediately below this horizon (Sample 469-14-1, 60-62 $\mathrm{cm}$ ) are assigned to the lower part of Paleomagnetic Epoch 7, whereas diatoms immediately above, in the lower part of Core $469-13$, offer only poor stratigraphic control.

At Site 438 off Japan, Barron (1980) connected formation of the late late Miocene hiatus, which covered the upper half of Paleomagnetic Epoch 7 and the lower part of Epoch 6, to the erosion by bottom waters stimulated by high-latitude cooling. At Site 158, Keigwin (1979) states that a $0.8 \%$ positive increase in the $\delta^{18} \mathrm{O}$ of benthic foraminifers at 136 to 142 meters sub-bottom depth marks a period of significant Antarctic glaciation. 
Diatoms of this interval are assigned to the lower part of Paleomagnetic Epoch 6 on the basis of the presence of Nitzschia reinholdii without Thalassiosira praeconvexa (J. A. Barron, unpublished data). Similarly, Keller (1980) related increased planktonic foraminifer dissolution in the North Pacific during the interval from 6.8 to 6.4 Ma to climatic cooling caused by Antarctic ice growth. As with the other hiatuses, it seems reasonable to invoke increased Antarctic bottom-water activity associated with periods of Antarctic ice growth as the agent responsible for the late late Miocene hiatus. Mechanical erosion of bottom sediments, corrosion of biogenic opal, or a combination of the two conceivably could have resulted in the widespread distribution of the hiatus.

\section{FURTHER COMMENTS \\ ON MIOCENE PALEOCLIMATOLOGY}

Middle and upper Miocene sections recovered during Leg 63 contain a mixture of middle- to high-latitude and low-latitude diatom assemblages. As one proceeds from north to south, the low-latitude component increases at all intervals. Within the composite section recovered at Sites 471 and 472 off southern Baja California, virtually all of the tropical diatom datum levels recognized by Burckle (1978) in the middle middle Miocene through upper Miocene can be identified. One exception is an interval equivalent to most of Paleomagnetic Epoch 10, Subzone d of the Denticulopsis hustedtii-D. lauta Zone. The low-latitude diatom Coscinodiscus vetustissimus var. javanica is absent from this interval at Site 472, and the cool-water diatom Denticulopsis hustedtii is common throughout the entire interval rather than being restricted to its lowermost part, as it is in the equatorial Pacific. For these reasons as well as the relatively common occurrence of other cool-water diatoms including Coscinodiscus marginatus, Rhizosolenia barboi, and Thalassionema hirosakiensis, the interval of Subzone d (ca. 11-10 Ma) is interpreted to be a period of relative cooling.

At Site 469, warm-water diatoms such as Actinocyclus ellipticus, Coscinodiscus gigas var. diorama, and C. yabei are relatively common in an interval from the upper half of Subzone b to the lowermost part of Subzone c of the $D$. hustedtii-D. lauta Zone. The restricted occurrence of Bogorovia spp. and Coscinodiscus tuberculatus within this interval are supportive of the possibility that warming conditions prevailed during this period of time (ca. 12.8-12.2 Ma). At Site 173 off northern California, the consistent presence of Craspedodiscus coscinodiscus and Bogorovia paleacea within the correlative interval (Cores 173-22 and 173-21) are also supportive of a relative warming trend compared to immediately older and younger intervals.

At Site 173 the relative warm interval (ca. 12.8-12.2 $\mathrm{Ma}$ ) is separated from the early late Miocene cool interval (ca. 11-10 Ma) by a hiatus between Cores 173-21 and 173-20 (186 m sub-bottom depth). As was discussed earlier, this hiatus and an equivalent hiatus apparently present at Site 469 correspond with a period of Antarctic ice growth recorded by Keigwin (1979). At Site 173, Ingle (1973) records a major change from warm-temperate to cool-temperate to subarctic planktonic foraminiferal faunas across this hiatus.

\section{PLIOCENE DISSOLUTION}

At both Sites 467 and 469 off southern California, lowermost Pliocene and upper Pliocene diatomaceous sediments are separated by an interval containing only rare, poorly preserved diatoms reworked from the Miocene. The sediment accumulation rate curves for Sites 467 and 469 (see site chapters, this volume) both suggest an age of about 4.5 to $2.5 \mathrm{Ma}$ for this diatom-poor interval. Reduced upwelling with resultant decreased diatom productivity is a possible explanation for the scarcity of diatoms within this interval. A decrease in upwelling would likely accompany a slackening of the California Current during a period of relative warming.

Planktonic foraminiferal evidence from the middlelatitude North Pacific is generally supportive of a relatively warmer early Pliocene. Keller (1979) identifies major cooling events across the Miocene/Pliocene boundary and at about $2.5 \mathrm{Ma}$. She reports warm stable conditions between about 4.0 and $3.3 \mathrm{Ma}$, a brief cool event at about 3.2 to $3.0 \mathrm{Ma}$, and fluctuating climatic conditions between 3.0 and $2.6 \mathrm{Ma}$. Similarly, Poore (this volume) reports warming periods in the lower Pliocene and in the middle part of the Pliocene in Leg 63 sediments.

\section{CONCLUSIONS}

1. The middle- to high-latitude North Pacific diatom zonation of Koizumi $(1973,1975)$ and Barron $(1980)$ is applicable off southern California and Baja California, with the exception of an interval from the upper part of the upper Miocene through the lowermost Pliocene. Within this interval, because of the absence of Denticulopsis kamtschatica, a local zonation is substituted, namely Barron's (1976a) North Pacific Diatom Zones XI through IX (herein renamed).

2. At least 25 middle and upper Miocene diatom datum levels allow precise correlation along the length of the present-day California Current from Site $\mathbf{4 7 2}$ $\left(23^{\circ} \mathrm{N}\right)$ to Site $173\left(40^{\circ} \mathrm{N}\right)$.

3 . These correlations reveal three intervals of widespread hiatus development-ca. 12 to $11 \mathrm{Ma}, 10$ to 9 $\mathrm{Ma}$, and 7.2 to $6.2 \mathrm{Ma}$ - which probably reflect intensification of bottom-water activity associated with highlatitude cooling and growth of Antarctic ice.

4. A brief warming trend probably occurred between about 12.8 and $12.2 \mathrm{Ma}$ in the area, as evidenced by the occurrence of relatively common warm-water taxa during this interval at Site $469\left(32^{\circ} 37^{\prime} \mathrm{N}\right)$ and Site 173 $\left(40^{\circ} \mathrm{N}\right)$.

5. The early late Miocene (ca. 11-10 Ma) was an interval of climatic cooling on the basis of the relative 
abundance of cool-water taxa at Site $472\left(23^{\circ} \mathrm{N}\right)$ and the difficulty in correlating this interval with the tropical Pacific.

6. Decreased diatom productivity off southern California during most of the early Pliocene (ca. 4.5-2.5 Ma) most likely reflects slackening of the California Current during a period of relative climatic warming.

\section{ACKNOWLEDGMENTS}

Dave Bukry, U.S. Geological Survey, La Jolla, California, and Lloyd Burckle, Lamont-Doherty Geological Observatory of Columbia University, reviewed the manuscript and offered valuable suggestions. I also wish to thank R. Z. Poore, Jack G. Baldauf, and F. M. Weaver for helpful discussion. Appreciation is due Mrs. Margaret Hanna for her kind hospitality at the California Academy of Sciences and to Herman Adler for providing excellent microscope slides of material from Solstice Canyon near Point Dume, California. In addition, I would like to thank Bilal Haq and Robert Yeats, the co-chiefs of Leg 63, for making samples available for study, as well as the entire Leg 63 crew for the productive and enjoyable atmosphere aboard the Glomar Challenger. I am also grateful to the following personnel of the U.S. Geological Survey, Menlo Park, for their assistance: Jack G. Baldauf for photography and drafting, Robert Oscarson for scanning electron microscope work, and Rose M. Trombley for typing the manuscript.

\section{REFERENCES}

Addicott, W. O., Barron, J. A., and Miller, J. W., 1978. Marine late Neogene sequence near Santa Cruz, California. In Addicott, W. O. (Ed.), Neogene Biostratigraphy of Selected Areas in the California Coast Ranges: U.S. Geol. Surv. Open-File Rep., 78-446:97-109.

Baldauf, J. G., and Barron, J. A., 1980. Actinocyclus ingens var. nodus: a new, stratigraphically useful diatom of the circum-North Pacific. Micropaleontology, 26:103-110.

Barron, J. A., 1973. Late Miocene-early Pliocene paleotemperatures for California from marine diatom evidence. Palaeogeogr., $\mathrm{Pa}$ laeoclimatol., Palaeoecol., 14:277-291.

1975. Late Miocene-early Pliocene marine diatoms from southern California. Palaeontographica, 151(B):97-170.

1976a. Revised Miocene and Pliocene diatom biostratigraphy of Upper Newport Bay, Newport Beach, California. Mar. Micropaleontol., 1:27-63.

1976b. Middle Miocene-lower Pliocene marine diatom and silicoflagellate correlations in the California area. In Fritsche, A. E., Best, H. T., Jr., and Wornardt, W. W. (Eds.), The Neogene Symposium. Soc. Econ. Paleontol. Mineral., Pacific Section, Ann. Mtg., San Francisco, California, April, 1976, pp. 117-124. , 1980. Lower Miocene to Quaternary diatom biostratigraphy of DSDP Leg 57, off northeastern Japan. In Scientific Party, Init. Repts. DSDP, 56, 57, Pt. 2, Washington (U.S. Govt. Printing Office), 641-686.

Berggren, W. A., and Van Couvering, J. A., 1974. The Late Neogene: biostratigraphy, geochronology and paleoclimatology of the last 15 million years in marine and continental sequences. Palaeogeogr., Palaeoclimatol., Palaeoecol., 16:1-216.

Bukry, D., 1973. Low-latitude coccolith biostratigraphic zonation. In Edgar, N. T., Saunders, J. B., et al., Init. Repts. DSDP, 15: Washington (U.S. Govt. Printing Office), 685-703.

Burckle, L. H., 1972. Late Cenozoic planktonic diatom zones from the eastern equatorial Pacific. Nova Hedwigia Beih., 39:217-246.

1977. Pliocene and Pleistocene diatom datum levels from the equatorial Pacific. Quat. Geol., 7:330-340.

1978. Early Miocene to Pliocene diatom datum levels for the equatorial Pacific. Republic of Indonesia, Geol. Research and Development Centre, Spec. Pub. No. 1:25-44.

Burckle, L. H., Hammond, S. R., and Seyb, S. M., 1978. A stratigraphically important new diatom from the Pleistocene of the North Pacific. Pac. Sci., 32(2):209-214.

Burckle, L. H., and Opdyke, N., 1977. Late Neogene diatom correlations in the circum-North Pacific. Proc. Ist Int. Congress on Pacific Neogene Stratigraphy, Tokyo, 1976: Tokyo (Kaiyo Shuppan Co. Ltd.), pp. 255-284.
Dalrymple, G. B., 1979. Research note: critical tables for conversion of K-Ar ages from old to new constants. Geology, 7(11):558-560.

Demere, T. A., 1978. Pliocene to middle Pleistocene siliceous microfossil biostratigraphy of DSDP Sites 173,183 , and 47.2 , northern Pacific Ocean [M.S. thesis]. University of Southern California.

Dymond, J. R., 1966. Potassium-argon geochronology of deep sea sediments. Science, 152:1239-1241.

Ehrenberg, C. G., 1838. Die Infusionthierchen als Vollkommene Organismen. Ein Blick in das Tiefere Organische Leben der Natur (Vols. I-XVII): Leipzig (Leopold Voss), 1-548.

Harper, H. E., Jr., 1977. Diatom biostratigraphy of the MiocenePliocene boundary in marine strata of the Circum-North Pacific [Ph.D. dissert.]. Harvard University.

Heath, G. R., 1974. Dissolved silica and deep-sea sediments. In Hay, W. W. (Ed.), Studies in Paleo-oceanography: Tulsa (Soc. Econ. Paleontol. Mineral. Spec. Publ. 20), pp. 77-93.

Ingle, J. C., Jr., 1973. Neogene Foraminifera from the northeastern Pacific Ocean, Leg 18, Deep Sea Drilling Project. In Kulm, L. D., von Huene, R., et al., Init. Repts. DSDP, 18: Washington (U.S. Govt. Printing Office), 239-244.

Kanaya, T., 1971. Some aspects of pre-Quaternary diatoms in the oceans. In Funnell, B. M., and Riedel, W. R. (Eds.), The Micropaleontology of Oceans: Cambridge (Cambridge Univ. Press), pp. 545-565.

Keigwin, L. D., Jr., 1979. Late Cenozoic stable isotope stratigraphy and paleoceanography of DSDP sites from the east equatorial and north central Pacific Ocean. Earth Planet. Sci. Lett., 45(2): 361-382.

Keller, G., 1979. Late Neogene paleoceanography of the North Pacific DSDP Sites 173, 310, and 296. Mar. Micropaleontol., 4: 159-172.

1980. Middle to late Miocene datum levels and paleoceanography of the north and southeastern Pacific Ocean. Mar. Micropaleontol., 5:249-281.

Koizumi, I., 1973. The late Cenozoic diatom of Site 183-193, Leg 19, Deep Sea Drilling Project. In Creager, J. S., Scholl, D. W., et al., Init. Repts. DSDP, 19: Washington (U.S. Govt. Printing Office), 805-855.

1975. Late Cenozoic diatom biostratigraphy in the circumNorth Pacific region. Geol. Soc. Japan J., 81(10):611-627.

LaBrecque, J. L., Kent, D. V., and Cande, S. C., 1977. Revised magnetic polarity time scale for Late Cretaceous and Cenozoic time. Geology, 5:330-335.

Manikinen, E. A., and Dalrymple, G. B., 1979. Revised geomagnetic polarity time scale for the interval 0-5 m.y. b.p. J. Geophys. Res., 84(B2):615-626.

Moore, T. C., Jr., van Andel, Tj. H., Sancetta, C., et al., 1978. Cenozoic hiatus in pelagic sediments. Micropaleontology, 24:113-138.

Schrader, H.-J., 1973. Cenozoic diatoms from the northeast Pacific, Leg 18. In Kulm, L. D., von Huene, R., et al., Init. Repts. DSDP, 18: Washington (U.S. Govt. Printing Office), 673-797.

1974. Revised diatom stratigraphy of the Experimental Mohole drilling, Guadalupe Site. Proc. Calif. Acad. Sci. 4th ser., 39(23):517-562.

Tempere, J., and Peragallo, M., 1908. Les Diatomées du Monde Entier, 2nd ed.: Arcachon (Grez-sur-Loing [S.-et-M]), p. 60.

Theyer, F., and Hammond, S. R., 1974. Paleomagnetic polarity sequence and radiolarian zones, Brunhes to polarity Epoch 20. Earth Planet. Sci. Lett., 22:307-319.

\section{APPENDIX}

\section{Description of New Taxa}

Genus ANNELLUS Tempere in Tempere and Peragallo, 1908

Annellus californicus Tempere in Tempere and Peragallo, 1908, var. californicus

(Plate 6, Figs. 1, 2, 5, 7, 8; Plate 7, Figs. 4, 5)

Annellus californicus Tempere in Tempere and Peragallo, 1908, p. 60. A. californicus Tempere, Hanna, 1932, pl. 4, fig. 8.

A. californicus Tempere, Reinhold, 1937, pl. 6, figs. 1-4

Remarks. Annellus californicus var. californicus possesses a rather shallow invagination of the outer loculate wall (about 4-5 $\mu \mathrm{m}$ ) into the interior of the cylinder (Plate 7, Fig. 4). This results in the interior edge of the invaginated wall appearing sharp and nearly in focus when 
the valve is viewed from above (valve view, Plate 6, Figs. 1, 2). There is no ring of small pores located between the areolae and near the top of the valve visible in margin view (Plate 6, Figs. 5, 7, 8), as there is in A. californicus var. hannai (Plate 6, Figs. 9-12). Pores between the areolae are, however, present on the valve face (Plate 6, Fig. 1; Plate 7, Fig. 4).

Discussion. Tempere in Tempere and Peragallo (1908) recorded his type Annellus californicus from his Sample No. 112 from Santa Monica, California. Hanna (1932) recounted the search for the "celebrated piece of float picked up a few miles south of Santa Monica" from which Tempere's sample came. Hanna noted the lack of lower middle Miocene strata containing A. californicus in the immediate area and concluded that the likely source of the "Santa Monica float block" was strata exposed near Point Dume, approximately $30 \mathrm{~km}$ west of Santa Monica.

Recently, at the California Academy of Sciences in San Francisco, I examined Hanna's (1932) slide of Tempere's Sample No. 112. The slide contains diatoms assignable to the uppermost part of Subzone a of the Denticulopsis hustedtii-D. lauta Zone including Coscinodiscus plicatus, C. gigas var. diorama, Denticulopsis hustedtii, D. lauta, and Rouxia naviculoides. The silicoflagellates Mesocena circulus and $M$. elliptica are supportive of this assignment. Thus Sample No. 112 is coincident with the range of $A$. californicus var. californicus in Leg 63 material (Subzone a and b of the D. hustedtii-D. lauta Zone) and substantially younger than the range of $A$. californicus var. hannai, $\mathrm{n}$. var., which is restricted to Subzone a of the Denticulopsis lauta Zone in Leg 63 material (see Tables 2, 3 in preceding chapter) and in southern California (J. A. Barron, unpublished data).

I have observed $A$. californicus var. californicus in Reinhold's (1937) Sample AP-7 from the Wonosari-series of Java and in Core 25 and Sample 77B-26-2, 20-22 cm of DSDP Hole 77B in the eastern equatorial Pacific. Unlike Burckle in Opdyke, Burckle, and Todd (1974), I do not record $A$. californicus from Core 24 of Hole 77B. These Hole 77B occurrences are early middle Miocene in age and are coincident with Opdyke, Burckle, and Todd's (1974) reported range of $A$. californicus in the equatorial Pacific. The younger range in California (middle middle Miocene) may be an exception to the more commonly recognized early middle Miocene range of $A$. californicus; however, Schrader (1979) also reports $A$. californicus coincident with Denticulopsis hustedtii in sediments assigned to the middle middle Miocene Coccolithus miopelagicus Zone of calcareous nannofossils by Bukry (1979) at Site 408 in the North Atlantic; $A$. californicus occurs at an equivalent horizon (Sample 77B-22-2, 35-37 cm) in Hole $77 \mathrm{~B}$ in the eastern equatorial Pacific (J. A. Barron, unpublished data).

Annellus californicus var. hannai, n. var.

(Plate 6, Figs. 4, 6, 9, 11, 12; Plate 7, Figs. 1-3)

Annellus californicus Tempere, Hanna, 1932, pl. 4, figs. 5-7 (not 8).

Description. This variety is distinguished from the type form of $A$. californicus by the more deeply invaginated outer loculate wall into the interior of the cylinder $(10-14 \mu \mathrm{m})$ (Plate 7, Fig. 1). In valve view, the inner edge of the loculate wall therefore comes into focus well below the top surface of the valve (Plate 6, Figs. 3, 4, 6), and the top of the cylinder appears somewhat rounded. A single row of pores is located between the areolae approximately one to two areolae below the top surface of the valve (Plate 7, Figs. 1, 2), and the appearance of these pores in margin view (Plate 6, Figs. 9-12) also serves to distinguish $A$. californicus var. hannai from $A$. californicus var. californicus. Observed specimens ranged in size from $36 \times 36 \mu \mathrm{m}$ to $73 \times 54 \mu \mathrm{m}$ (width $\times$ height), whereas no specimens of $A$. californicus var. californicus have been observed larger than $57 \times 42 \mu \mathrm{m}$. Annellus californicus var, hannai also appears to be more heavily silicified than A. californicus var. californicus (see Plate 7), and abraded specimens may exhibit distinct hyaline areas between the areolae in margin view (Plate 6, Figs. 9, 12; Plate 7, Fig. 3).

Distribution. Annellus californicus var. hannai is restricted to lower middle Miocene Subzone a of the Denticulopsis lauta Zone in California.

Holotype. Plate 7, Figures 1, 2, USNM 304194.

Isotypes. Plate 6, Figure 4, USNM 304195; Plate 6, Figure 9, USNM 304196; Plate 7, Figure 3, USNM 304197.

Type locality. Dart core sample Mf5208 from the southern California Continental Borderland, $33.196^{\circ} \mathrm{N}, 119.262^{\circ} \mathrm{W}$.
Genus BOGOROVIA Jousé, 1974

Bogorovia paleacea (Grunow) Jousé, 1974 Bogorovia paleacea var. elongata, n. var. (Plate 4, Figs. 11, 12)

Description. This variety is distinguished by its elongated and nearly symmetrically shaped valves, which range in size from $40 \times 6$ $\mu \mathrm{m}$ to $72 \times 9 \mu \mathrm{m}$. The ratio of length to width varies from 7:1 to $9: 1$ and is generally greater in larger specimens. The subangular areolae are arranged subparallel to the pervalvar axis, with six to seven in 10 $\mu \mathrm{m}$.

Remarks. Burckle (1972) noted that this "narrower, longer and more symmetrical representative" of $B$. paleacea is generally rare, but tends to be more common in the lower upper Miocene of the eastern equatorial Pacific. At Site 472, it is restricted to lower upper Miocene Subzone d of the Denticulopsis hustedtii-D. lauta Zone.

Holotype. Plate 4, Figure 11, USNM 304198.

Type locality. Sample DSDP 77B-15-6, 23-25 cm, eastern equatorial Pacific.

\section{Genus COSCINODISCUS Ehrenberg, 1838}

Coscinodiscus temperei Brun in Brun and Tempere, 1889, var. temperei, emended

(Plate 3, Figs. 7, 8)

Coscinodiscus temperei Brun in Brun and Tempere, 1889, pl. 7, fig. 2. C. temperei Brun, Barron, 1980, pl. 4, fig. 5.

C. temperei Brun, Koizumi, 1975a, pl. 2, fig. 6.

Description. Brun notes that specimens range in size from $60 \times 40$ $\mu \mathrm{m}$ to $85 \times 55 \mu \mathrm{m}$ (length $\times$ width) and that there are five to seven areolae in $10 \mu \mathrm{m}$. Brun's description (Brun and Tempere, 1889, p. 5) is emended here to include a decrease in size areolae towards the margin to about ten in $10 \mu \mathrm{m}$ and the presence of hyaline areas between the areolae on one of the plications.

Distribution. This taxon is present in upper Miocene to lowermost Pliocene sediments from Japan and in the high-latitude North Pacific but was not observed in Leg 63 sediments.

\section{Coscinodiscus temperei var. delicata, n. var. (Plate 3, Figs. 1, 3, 4)}

Coscinodiscus temperei Brun, Schrader, 1974a, pl. 2, figs. 29-33. Cymatothea temperii (Brun) Hendey, Jousé, 1977, pl. 51, fig. 12 (not pl. 50, fig. 5).

Description. This variety possesses finer areolae and the valve is less elongated in outline and generally smaller in size than $C$. temperei var, temperei. Observed specimens range in size from $16 \times 15 \mu \mathrm{m}$ to $53 \times 43 \mu \mathrm{m}$ (length $\times$ width). Areolae are subpolygonal and range in size from ten in $10 \mu \mathrm{m}$ near the center of the valve to thirteen in $10 \mu \mathrm{m}$ near the margin. The areolae are arranged in a subfasciculated pattern. Unlike C. temperei var. temperei, no hyaline areas are present on either of the plications. At $500 \times$ and lower magnifications this variety exhibits a distinct light yellow brown interference color.

Distribution. This variety preferred low to middle latitudes, where it ranged from the late middle Miocene (lowermost part of the Paleomagnetic Epoch 12; Burckle, personal communication, 1979) to the early late Miocene.

Holotype. Plate 3, Figure 1, USNM 304199.

Isotypes. Plate 3, Figure 3, USNM 304200; Plate 3, Figure 4, USNM 304201.

\section{TAXONOMIC NOTES AND ILLUSTRATION REFERENCES}

\section{Diatoms}

Actinocyclus ellipticus var. elongatus (Grunow) Kolbe, 1954, pl. 3, fig. 28. (Plate 1, Fig. 8)

Actinocyclus ellipticus var, javanicus Reinhold, 1937, pl. 1, figs. 7, 8. (Plate 1, Figs. 5, 6)

Actinocyclus ellipticus var. moronensis (Deby) Kolbe, 1954, pl. 3, figs. 29, 30. (Plate 1, Fig. 10).

Actinocyclus ellipticus forma lanceolatus Kolbe, 1954, pl. 3, fig. 27. (Plate 1, Fig. 7)

Actinocyclus ellipticus var. 1. Remarks: Tabulated here are forms that are nearly circular in outline; i.e., the length approximates the 
width. The areolae of the central two-thirds of the valve are separated by distinct hyaline areas. (Plate 1, Fig. 4)

Actinocyclus ellipticus Grunow, s. ampl.: Schrader, 1973, pl. 8, figs. 7-9, 12-14, 16, 17. (Plate 1, Fig. 9)

Actinocyclus ingens Rattray: flat form-Schrader, 1973, pl. 18, figs. 2-4, 7; undulated form-Baldauf and Barron, 1980, pl. 1, figs. 1, 2. Remarks: The original type concept of $A$. ingens Rattray, 1890, included specimens with undulated valves with depressed centers. Such forms are tabulated here as the undulated form. Specimens with more nearly flat valves are tabulated here as the flat form. (Undulated form-Plate 1, Fig. 2; flat form-Plate 1, Fig. 1)

Actinocyclus ingens var. nodus Baldauf in Baldauf and Barron, 1980, pl. 1, figs. 5-9. Synonym: $A$. ingens var. 1, Barron, 1980, pl. 5, figs. 8,12 . Remarks: This variety possesses an undulating valve surface with a central area raised to an equal elevation as the submarginal ring. (Plate 1, Fig. 3)

Bogorovia paleacea var. paleacea (Grunow) Jousé: Synonym: Coscinodiscus paleaceus Grunow, Burckle, 1972, pl. 1, figs. 7, 8. (Plate 4, Fig. 13)

Bogorovia praepaleacea (Schrader) Jousé: As Coscinodiscus praepaleaceus Schrader, 1973, pl. 3, figs. 1-9. (Plate 4, Fig. 14)

Bogorovia tatsunokuchiensis (Koizumi) Jousé: Synonym: Cussia tatsunokuchiensis (Koizumi) Schrader, Barron, 1980, pl. 1, fig. 31, pl. 4, fig. 3. (Plate 4, Fig. 17)

Cestodiscus peplum Brun: Lohman, 1974, pl. 3, fig. 2; Reinhold, 1937 , pl. 7 , figs. $10,11$.

Coscinodiscus aeginensis Schmidt, 1888, in Schmidt et al., 1874, pl. 113, figs. 13, 14; Kolbe, 1954, pl. 1, figs. 9, 10? Synonym: Coscinodiscus vetustissimus Pantocsek, Kanaya, 1971, pl. 40.2, fig. 1.

Coscinodiscus endoi Kanaya: Schrader, 1973, pl. 7, figs. 14, 21, pl. 20, figs. 1, 2. Remarks: A broad concept is used in this report and includes forms that show strong affinities with $C$. tabularis var. egregius (Rattray) Hustedt.

Coscindiscus gigas var. diorama (Schmidt) Grunow: Kanaya, 1971, pl. 40.1, fig. 1; Wornardt, 1967, fig. 25 .

Coscinodiscus lewisanus Greville: Schrader, 1973, pl. 8, figs. 1-6, 10, 15.

Coscinodiscus marginatus Ehrenberg: Schrader, 1973, pl. 20, figs. 7, $10,12,13$.

Coscinodiscus nodulifer Schmidt: Kanaya, 1971, pl. 40.3, figs. 1-4. (Plate 2, Figs. 2, 3)

Coscinodiscus nodulifer var. cyclopus Jousé: Jousé, 1977, pl. 45, figs. 11,15 , pl. 48 , figs. $1-6$, pl. 52 , figs. $6-7$, pl. 77 , fig. 17 , pl. 78 , figs. $1-4$, pl. 79 , fig. 16 .

Coscinodiscus nodulifer var. 1. Remarks: Forms with a prominent central nodule located next to a large (about $3 \mu \mathrm{m}$ ) subrounded areola are tabulated here. (Plate 2, Figs. 1, 4)

Coscinodiscus plicatus Grunow: Kanaya, 1971, pl. 40.4, figs. 4-6. (Plate 3, Fig. 6)

Coscinodiscus praeyabei Schrader, 1973, pl. 6, fig. 16, pl. 7, figs. 1720.

Coscinodiscus salisburyanus Lohman, 1948, pl. 7, fig. 5. (Plate 2, Fig. 5)

Coscinodiscus tuberculatus Greville: Kolbe, 1954, pl. 1, fig. 11.

Coscinodiscus yabei Kanaya: Schrader, 1973, pl. 6, figs. 1-6, 15; (Plate 3, Fig. 9)

Coscinodiscus sp. 1. Remarks: Forms that are intermediate in areolae pattern between $C$. salisburyanus and $C$. nodulifer are tabulated here. (Plate 2, Fig. 4)

Craspedodiscus coscinodiscus Ehrenberg: Kanaya, 1971, pl. 40.4, figs. 1-3.

Craspedodiscus rhombicus Grunow: Barron, 1976, pl. 1, fig. 10.

Delphineis angustata (Pantocsek) Andrews: Andrews, 1978, pl. 5, figs. 1-2, pl. 8, figs. 1-2.

Delphineis penelliptica Andrews: Abbott, 1978, pl. 1, fig. 6.

Denticulopsis dimorpha (Schrader) Simonsen, 1979: As Denticula dimorpha Schrader, 1973, pl. 1, figs. 37-39, 41-46 (not fig. 40). (Plate 4, Fig. 7)

Denticulopsis hustedtii (Simonsen and Kanaya) Simonsen, 1979: As Denticula hustedtii Simonsen and Kanaya, Schrader, 1973, pl. 2, figs. 28-34, 36-47. (Plate 4, Fig. 21)
Denticulopsis hyalina (Schrader) Simonsen, 1979: As Denticula hyalina Schrader, 1973, pl. 1, figs. 12-22. (Plate 4, Figs. 3, 4)

Denticulopsis sp. cf. D. kamtschatica (Zabelina) Simonsen, 1979: Barron, 1980, pl. 1, figs. 15-17. Remarks: Specimens tabulated here resemble $D$. kamtschatica (Zabelina) Simonsen but have seven to eleven pseudoseptae per $10 \mu \mathrm{m}$ rather than five to six per $10 \mu \mathrm{m}$.

Denticulopsis lauta (Bailey) Simonsen, 1979: As Denticula lauta Bailey, Schrader, 1973, pl. 2, figs. 14-24, 35. (Plate 4, Fig. 5)

Denticulopsis nicobarica (Grunow) Simonsen, 1979: As Denticula nicobarica Grunow, Schrader, 1976, pl. 4, figs. 19-21. (Plate 4, Fig. 6)

Denticulopsis norwegica (Schrader) Simonsen, 1979: As Denticula norwegica Schrader in Schrader and Fenner, 1976, pl. 1, fig. 38.

Denticulopsis praedimorpha (Akiba) n. comb.: Synonym: Denticula praedimorpha Akiba, Barron, 1980, pl. 1, figs. 18-20. (Plate 4, Figs. 8-10)

Denticulopsis punctata var. hustedtii (Schrader) Simonsen, 1979: As Denticula punctata f. hustedtii Schrader, 1973, pl. 1, figs. 23-24. (Plate 4, Fig. 1)

Denticulopsis seminae (Simonsen and Kanaya) Simonsen, 1979: Synonym: Denticula seminae Simonsen and Kanaya, Koizumi, 1975 b, pl. 1, figs. 1, 2.

Denticulopsis seminae var. fossilis (Schrader) Simonsen, 1979: Synonym: Denticula seminae var. fossilis Schrader, Koizumi, 1975b, pl. 1 , figs. 3,4 .

Denticulopsis sp. (spore?): Synonym: Denticula lauta Bailey (spore?), Schrader, 1973, pl. 2, fig. 25. (Plate 4, Fig. 2)

Hemiaulus polymorphus Grunow: Barron, 1976, pl. 2, fig. 11.

Hemidiscus cuneiformis Wallich: Kanaya, 1971, pl. 40.3, figs. 5, 6. Remarks: A broad concept of this taxon is used here and includes forms assigned to $\mathrm{H}$. simplicissimus Hanna and Grant.

Hemidiscus ovalis Lohman, 1938, pl. 22, fig. 9. (Plate 5, Fig. 8)

Lithodesmium asketogonium Barron, 1975, pl. 9, fig. 20, pl. 10, figs. $1,2$.

Lithodesmium cornigerum Brun: Wornardt, 1967, fig. 131.

Lithodesmium reynoldsii Barron, 1976, pl. 1, figs. 17, 18. (Plate 5, Fig. 7)

Mediaria splendida Sheshukova-Poretzkaya: Schrader, 1973, pl. 3, figs. 14,15 .

Nitzschia challengeri Schrader, 1973, pl. 5, figs. 10-14, 34. (Plate 4, Fig. 19)

Nitzschia cylindrica Burckle: Schrader, 1974b, pl. 6, figs. 26-34, 36-38.

Nitzschia fossilis (Frenguelli) Kanaya: Schrader, 1973, pl. 4, figs. 4, 5, 9-11, 24, 25.

Nitzschia heteropolica Schrader, 1973, pl. 26, figs. 1, 2.

Nitzschia jouseae Burckle: Schrader, 1974b, pl. 7, figs. 14-23.

Nitzschia marina Grunow: Schrader, 1973, pl. 4, figs. 17-19.

Nitzschia miocenica Burckle, 1972, pl. 2, figs. 10-15. Remarks: Elongate forms are tabulated separately after Burckle (personal communication, 1979). Elongate forms-Burckle, 1972, pl. 2, fig. 15; Schrader, 1974b, pl. 5, figs. 10, 11.

Nitzschia pliocena (Brun) Kanaya and Koizumi: Barron, 1980, pl. 2, figs. $1,2$.

Nitzschia porteri Frenguelli sensu Burckle, 1972, pl. 2, fig. 16. (Plate 4, Fig. 20)

Nitzschia praereinholdii Schrader, 1973, pl. 5, figs. 20, 23-26. (Plate 4, Fig. 16)

Nitzschia reinholdii Kanaya and Koizumi: Schrader, 1973, pl. 4, figs. 12-16, pl. 5, figs. 1-9. (Plate 4, Fig. 15)

Nitzschia rolandii Schrader, 1973, pl. 5, figs. 31, 42?, pl. 26, figs. 3, 4. (Plate 4, Fig. 18)

Pseudoeunotia doliolus (Wallich) Grunow: Schrader, 1973, pl. 4, figs. 1, 3, 6-8.

Raphidodiscus marylandicus Christian: Hanna, 1932, pl. 14, figs. 3-4.

Rhaphoneis miocenica Schrader, 1973, pl. 25, figs. 1, 11.

Rhizosolenia barboi Brun: Schrader, 1973, pl. 24, figs. 4, 7.

Rhizosolenia curvirostris Jousé: Koizumi, 1973, pl. 5, figs. 29-31.

Rhizosolenia matuyamai Burckle in Burckle, Hammond, and Seyb, 1978, figs. 3-6.

Rhizosolenia miocenica Schrader, 1973, pl. 10, figs. 2-6, 9-11.

Rhizosolenia praebarboi Schrader, 1973, pl. 24, figs. 1-3. 
Rouxia californica Peragallo: Schrader, 1973, pl. 3, figs. 18-20, $22,26$.

Rouxia diploneides Schrader, 1973, pl. 3, figs. 24, 25.

Rouxia fusiformis Tsumura: Barron, 1976, pl. 3, figs. 18, 19. Synonym: Rouxia yabei Hanna, Schrader, 1973, pl. 3, fig. 23 (not fig. 21). (Plate 5, Fig. 11)

Rouxia naviculoides Schrader, 1973, pl. 3, figs. 27-32.

Synedra jouseana Sheshukova-Poretzkaya: Schrader, 1973, pl. 23, figs. 21-23, 25, 38 .

Synedra jouseana var. 1: Barron, 1980, pl. 1, fig. 33. Remarks: Tabuated here are the more robust and less elongated forms.

Thalassionema hirosakiensis (Kanaya) Schrader, 1973, pl. 23, figs. 31-33. (Plate 5, Fig. 4)

Thalassionema nitzschioides Grunow: Schrader, 1973, pl. 23, figs. 6, $8-10,12,13,34$.

Thalassiosira antiqua (Grunow) Cleve-Euler: Schrader, 1973, pl. 11, fig. 25, pl. 25, fig. 19.

Thalassiosira burckliana Schrader, 1974b, pl. 1, figs. 21-26. Synonym: Thalassiosira nativa Sheshukova-Poretzkaya, Schrader, 1973, pl. 11, figs. 23-24. (Plate 5, Fig. 2)

Thalassiosira convexa var. aspinosa Schrader, 1974b, pl. 2, figs. 8-9, 13a-21.

Thalassiosira excentrica (Ehrenberg) Cleve: Schrader, 1973, pl. 25, fig. 17; Barron, 1976, pl. 2, fig. 18.

Thalassiosira leptopus (Grunow) Hasle and Fryxell, 1977, figs. 1-14, 94-96. Synonyms: Coscinodiscus lineatus Ehrenberg, Reinhold, 1937, pl. 11, fig. 7. C. lineatus var. leptopus Grunow, Barron, 1976, pl. 1, figs. $6,7$.

Thalassiosira miocenica Schrader, 1974b, pl. 22, figs. 1-5, 11-13. (Plate 5, Fig. 3)

Thalassiosira nativa Sheshukova-Poretzkaya, sensu Barron, 1975, pl. 14, fig. 4. Synonym: Thalassiosira oestrupii (Ostenfeld) Proshkina-Lavrenko, Barron, 1975, pl. 14, figs. 5, 6.

Thalassiosira oestrupii (Ostenfeld) Proshkina-Lavrenko: Schrader, 1973, pl. 11 figs. 16-22, 26-33, 39-45. (Plate 5, Fig. 6)

Thalassiosira sp. 1: Barron, 1980, pl. 5, figs. 6, 7. Synonym: Thalassiosira praeconvexa Burckle, Schrader, 1973, pl. 11, figs. 10-15. (Plate 5, Fig. 5)

Thalassiosira sp. 2. Synonym: Thalassiosira sp. 3, Barron, 1976, pl. 2, figs. 22, 23. Remarks: This taxon has a distinctive light yellow interference color (Plate 5, Fig. 1)

Thalassiothrix longissima Cleve and Grunow: Schrader, 1973, pl. 23, figs. $7,17,18$.

Thalassiothrix sp. 1. Remarks: The valves are characterized by a gradual swelling towards the apex, although they taper sharply at the apex. (Plate 5, Fig. 12)

Triceratium cinnamomeum Greville: Schrader, 1974b, pl. 20, figs. 8,11 .

\section{Silicoflagellates}

Dictyocha aspera var. clinata Bukry, 1975, pl. 1, figs. 1-5.

Dictyocha neonautica var. neonautica Bukry, in press: Synonym: Dictyocha navicula Ehrenberg, Bukry and Foster, 1973, pl. 3, figs. $6,7$.

Dictyocha neonautica var. cocosensis Bukry, in press: Synonym: Dictyocha navicula Ehrenberg, Bukry and Foster, 1973, pl. 3, fig. 8.

Distephanus pseudofibula (Schulz) Bukry: Barron, 1976, pl. 3, fig. 29; Barron, 1980, pl. 4, fig. 7.

Mesocena apiculata var. curvata Bukry, 1976, pl. 2, figs. 15-16: Barron, 1980, pl. 5, fig. 16. (Plate 5, Fig. 10)

Mesocena elliptica (Ehrenberg) Ehrenberg: Synonym: Mesocena elliptica Bachman and Papp, Ling, 1977, pl. 3, fig. 2.

Mesocena hexalitha Bukry, this volume: Synonym: Mesocena hexagona Haeckel, Barron, 1976, pl. 3, figs. 28, 33; Ling, 1977, pl. 3, fig. 3. (Plate 5, Fig. 9)

Mesocena quadrangula Ehrenberg ex Haeckel: Bukry, 1973, pl. 7, figs. 1-5.

\section{REFERENCES}

Abbott, W. H., 1978. Correlation and zonation of Miocene strata along the Atlantic margin of North America using diatoms and silicoflagellates. Mar. Micropaleontol., 3:15-34.
Andrews, G. W., 1978. Marine diatom sequence in Miocene strata of the Chesapeake Bay region, Maryland. Micropaleontology, 24: 371-406.

Baldauf, J. G., and Barron, J. A. 1980. Actinocyclus ingens var. nodus: A new, stratigraphically useful diatom of the circum-North Pacific. Micropaleontology, 26:103-110.

Barron, J. A., 1975. Late Miocene-early Pliocene marine diatoms from southern California. Palaeontographica, 151(B):97-170.

, 1976. Revised Miocene and Pliocene diatom biostratigraphy of Upper Newport Bay, Newport Beach, California. Mar. Micropaleontol., 1:27-63.

, 1980. Lower Miocene to Quaternary diatom biostratigraphy of DSDP Leg 57, off northeastern Japan. In Scientific Party, Init. Repts. DSDP, 56, 57, Pt. 2, Washington (U.S. Govt. Printing Office), 641-686.

Brun, J., and Tempere, J., 1889. Diatomées fossiles du Japan. Mem. Soc. Phys. Hist. Nat. Geneve, 30(9):3-75.

Bukry, D., 1973. Coccolith and silicoflagellate stratigraphy, Deep Sea Drilling Project Leg 18, eastern North Pacific. In Kulm, L. D., von Huene, R., et al., Init. Repts. DSDP, 18: Washington (U.S. Govt. Printing Office), 817-831. 1975. Coccolith and silicoflagellate stratigraphy, northwestern Pacific Ocean, Deep Sea Drilling Project Leg 32. In Larson, R. L., Moberly, R., et al., Init. Repts. DSDP, 32: Washington (U.S. Govt. Printing Office), 677-701. 1976. Silicoflagellate and coccolith stratigraphy of the Norwegian-Greenland Sea, Deep Sea Drilling Project Leg 38. In Talwani, M., Udintsev, G., et al., Init. Repts. DSDP, 38: Washington (U.S. Govt. Printing Office), 843-855.

1979. Coccolith and silicoflagellate stratigraphy, northern Mid-Atlantic Ridge and Reykjanes Ridge, Deep Sea Drilling Project Leg 49. In Luyendyk, B. P., Cann, J. R., et al., Init. Repts. DSDP, 49: Washington (U.S. Govt. Printing Office), 551-581. in press. Synthesis of silicoflagellate stratigraphy for Maestrichtian to Pleistocene. In Douglas, R. G. (Ed.), DSDP Symposium: Am. Assoc. Pet. Geol. Soc. Econ. Paleontol. Mineral. Spec. Publ.

Bukry, D., and Foster, J. H., 1973. Silicoflagellate and diatom stratigraphy, Leg 16, Deep Sea Drilling Project. In van Andel, Tj. H., Heath, G. R., et al., Init. Repts. DSDP, 16: Washington (U.S. Govt. Printing Office), 815-869.

Burckle, L. H., 1972. Late Cenozoic planktonic diatom zones from the eastern equatorial Pacific. Nova Hedwigia Beih., 39:217-246.

Burckle, L. H., Hammond, S. R., and Seyb, S. M., 1978. A stratigraphically important new diatom from the Pleistocene of the North Pacific. Pac. Sci., 32(2):209-214.

Hanna, G. D., 1932. The diatoms of Sharktooth Hill, Kern County, California. Proc. Calif. Acad. Sci. 4th ser., 20(6):161-263.

Hasle, G. R., and Fryxell, G. A., 1977. The genus Thalassiosira: some species with a linear areola array. Nova Hedwigia Beih., 54:15-66.

Jousé, A. P., 1974. Diatoms of the Oligocene-Miocene biostratigraphic zones of tropical areas of the Pacific Ocean. Nova Hedwigia Beih., 45:333-364.

Jousé, A. P. (Ed.), 1977. Atlas of Microorganisms in Bottom Sediments of the Oceans: Moscow (Nauka).

Kanaya, T., 1971. Some aspects of pre-Quaternary diatoms in the oceans. In Funnell, B. M., and Riedel, W. R. (Eds.), The Micropaleontology of Oceans: Cambridge (Cambridge Univ. Press), pp. 545-565.

Koizumi, I., 1973. The late Cenozoic diatoms of Sites 183-193, Leg 19, Deep Sea Drilling Project. In Creager, J. S., Scholl, D. W., et al., Init. Repts. DSDP, 19: Washington (U.S. Govt. Printing Office), 805-855.

1975a. Late Cenozoic diatom biostratigraphy in the circum-North Pacific region. Geol. Soc. Japan J., 81(10):611-627. $1975 \mathrm{~b}$. Neogene diatoms from the western margin of the Pacific Ocean, Leg 31, Deep Sea Drilling Project. In Karig, D. E., Ingle, J. C., Jr., et al., Init. Repts. DSDP, 31: Washington (U.S. Govt. Printing Office), 779-819.

Kolbe, R. W., 1954. Diatoms from equatorial Pacific cores. In Petterson, H. (Ed.), Rep. Swed. Deep-Sea Exped. 1947-1948, 6(1):3-57.

Ling, H. Y., 1977. Late Cenozoic silicoflagellates and ebridians from the eastern North Pacific. Proc. Ist Int. Congress on Pacific 
Neogene Stratigraphy, Tokyo, 1976: Tokyo (Kaiyo Shuppan Co. Ltd.), pp. 205-233.

Lohman, K. E., 1938. Pliocene diatoms from the Kettleman Hills, California. U.S. Geol. Surv. Prof. Paper, 189-C:81-102.

, 1948. Middle Miocene diatoms from the Hammond Well. Cretaceous and Tertiary Subsurface Geology: Maryland Dept. Mines Geol. Bull., 2:151-187.

1974. Lower middle Miocene marine diatoms from Trinidad. Verh. Naturforsch. Ges. Basel, 84(1):326-360.

Opdyke, N. D., Burckle, L. H., and Todd, A., 1974. The extension of the magnetic time scale in sediments of the central Pacific Ocean. Earth Planet. Sci. Lett., 22:300-306.

Rattray, J., 1890. A revision of the genus Actinocyclus Ehr. Quekett Micro. Club. J., Ser. 2, 4:137-212.

Reinhold, T., 1937. Fossil diatoms of the Neogene of Java and their zonal distribution. Verh. Geol. Mijnbouwkd. Genoot. Ned. Kolon. Geol. Ser., 12:43-133.

Schmidt, A., 1984-1959. Atlas der Diatomaceenkunde: Leipzig (O. R. Resiland).

Schrader, H.-J., 1973. Cenozoic diatoms from the northeast Pacific, Leg 18. In Kulm, L. D., von Huene, R., et al., Init. Repts, DSDP, 18: Washington (U.S. Govt. Printing Office), 673-797. 1974a. Revised diatom stratigraphy of the Experimental Mohole drilling, Guadalupe Site. Proc. Calif. Acad. Sci. 4th ser., 39(23):517-562.

1974b. Cenozoic marine planktonic diatom stratigraphy of the tropical Indian Ocean. In Fisher, R. L., Bunce, E. T., et al., Init. Repts. DSDP, 24: Washington (U.S. Govt. Printing Office), 887-967.

1976. Cenozoic planktonic diatom biostratigraphy of the southern Pacific Ocean. In Hollister, C. D., Craddock, C., et al., Init. Repts. DSDP, 35: Washington (U.S. Govt. Printing Office), 605-671.

1979. Opal phytoplankton in DSDP Leg 49 samples. In Luyendyk, B. P., Cann, J. R., et al., Init. Repts. DSDP, 49: Washington (U.S. Govt. Printing Office), 589-593.

Schrader, H.-J., and Fenner, J., 1976. Norwegian diatom biostratigraphy and taxonomy. In Talwani, M., Udintsev, G., et al., Init. Repts. DSDP, 38: Washington (U.S. Govt. Printing Office), 921-1098.

Simonsen, R., 1979. The diatom systems: ideas on phylogeny. Bacillaria, 2:9-71.

Tempere, J., and Peragallo, M., 1908. Les Diatomées du Monde Entier, 2nd ed.: Arcachon (Grez-sur-Loing [S.-et-M]), p. 60.

Wornardt, W. W., Jr., 1967. Miocene and Pliocene marine diatoms from California. Cal. Acad. Sci. Occasional Papers, 63:1-108. 

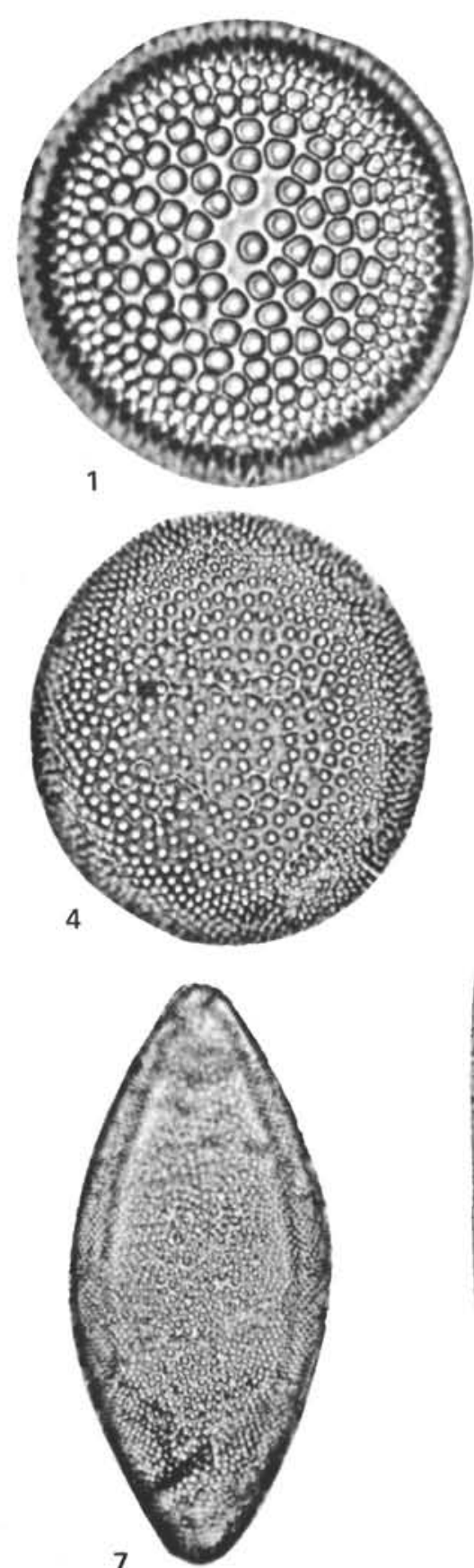
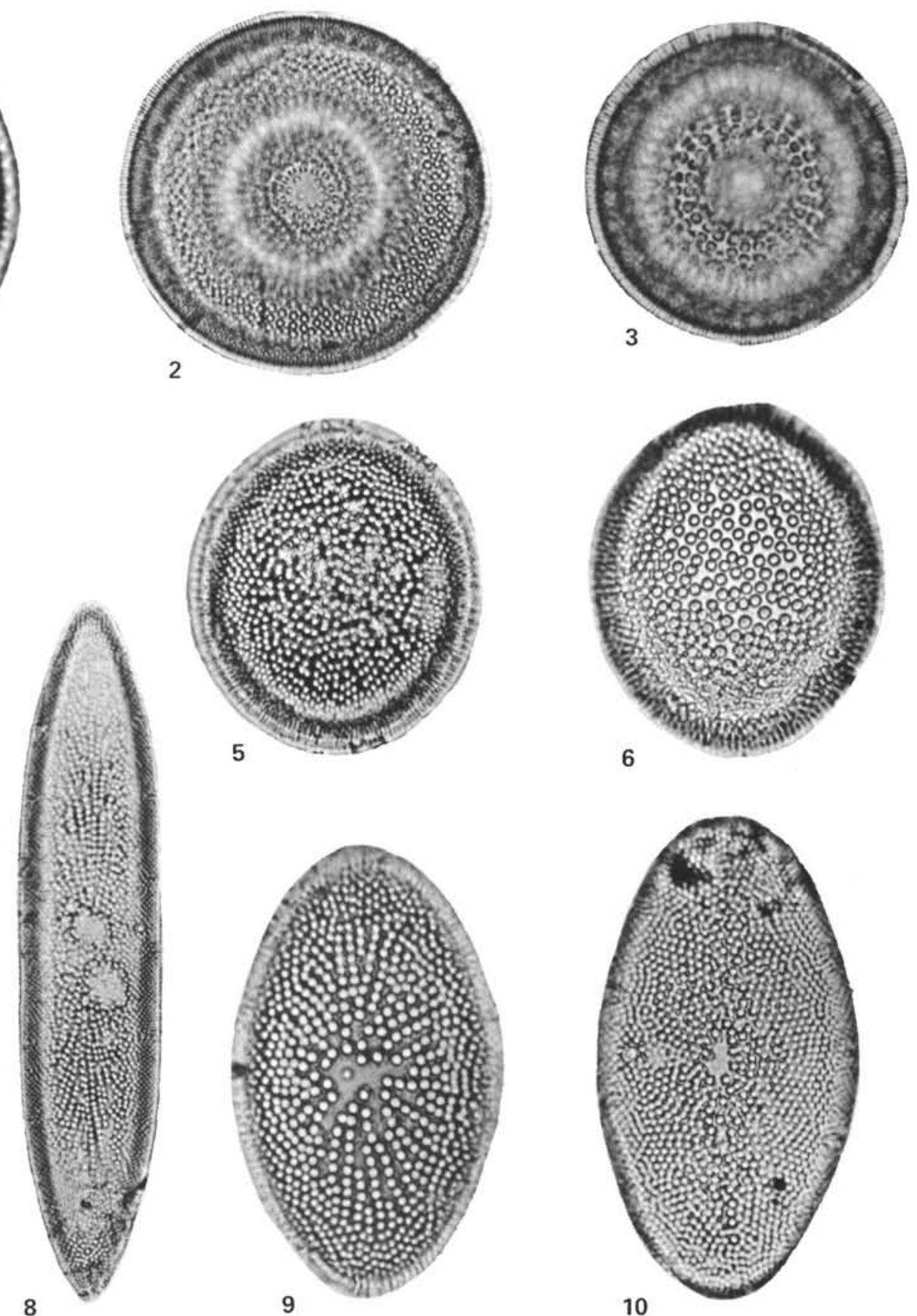

Plate 1. 1. Actinocyclus ingens Rattray (flat form). Sample 472-8-2, 120-122 cm. Diameter $28 \mu \mathrm{m}$. 2. Actinocyclus ingens Rattray (undulated form). Sample 468-7-1, 128-130 cm. Diameter $88 \mu \mathrm{m}$. 3. Actinocyclus ingens var. nodus Baldauf. Sample 468-7-1, 128-130 cm. Diameter 59 $\mu \mathrm{m}$. 4. Actinocyclus ellipticus var. 1. Sample $472-7-3,38-40 \mathrm{~cm}$. Length $36 \mu \mathrm{m}$. 5. Actinocyclus ellipticus var. javanicus Reinhold. Sample 472-7-3, 38-40 cm. Length $50 \mu \mathrm{m}$. 6. Actinocyclus ellipticus $\mathrm{cf}$. var. javanicus Reinhold. Sample 472-7-5, 70-72 cm. Length $34 \mu \mathrm{m}$. 7 . Actinocyclus ellipticus forma lanceolatus Kolbe. Sample $472-7-3,38-40 \mathrm{~cm}$. Length $80 \mu \mathrm{m}$. 8. Actinocyclus ellipticus var. elongatus (Grunow) Kolbe. Sample 472-7-3, 38-40 cm. Length $155 \mu \mathrm{m}$. 9. Actinocyclus ellipticus s. ampl. Sample 469-23-3, 7-9 cm. Length 45 $\mu \mathrm{m}$. 10. Actinocyclus ellipticus var. moronensis (Deby) Kc:Je. Sample 472-8-3, 120-122 cm. Length $48 \mu \mathrm{m}$. 

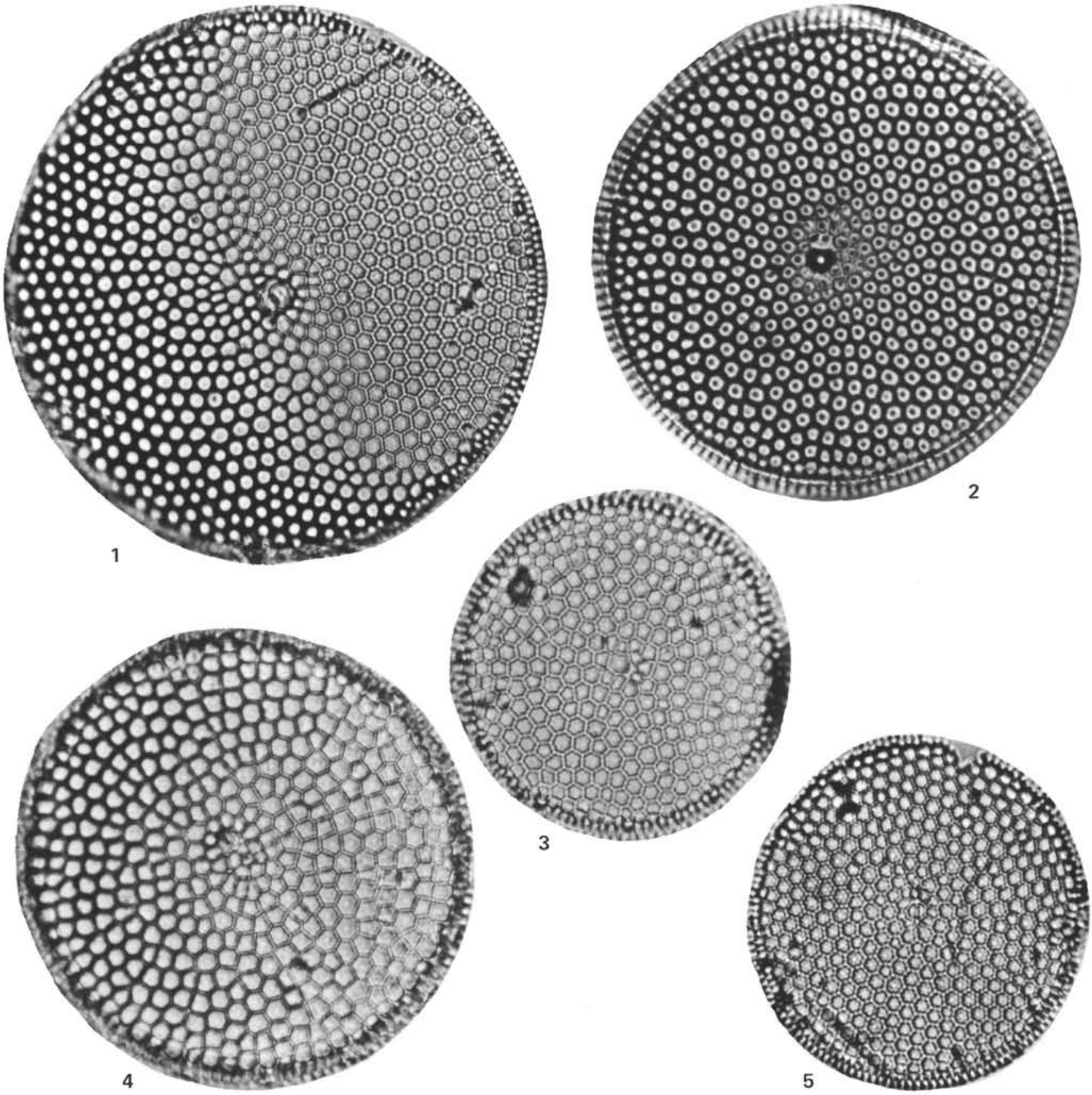

Plate 2. 1. Coscinodiscus nodulifer var. 1. Sample 472-8-3, 120-122 cm. Diameter $66 \mu \mathrm{m}$. 2-3. Coscinodiscus nodulifer Schmidt. (2) Sample 4695-5, 70-72 cm; diameter $56 \mu \mathrm{m}$. (3) Sample 469-17-1, 20-22 cm; diameter $37 \mu \mathrm{m}$. 4. Coscinodiscus sp. 1 . Intermediate form between C. salisburyanus and C. nodulifer. Sample 469-19-1, 40-42 cm. Diameter $50 \mu \mathrm{m}$. 5. Coscinodiscus salisburyanus Lohman. Sample 468-4-1, 90-92 cm. Diameter $39 \mu \mathrm{m}$. 

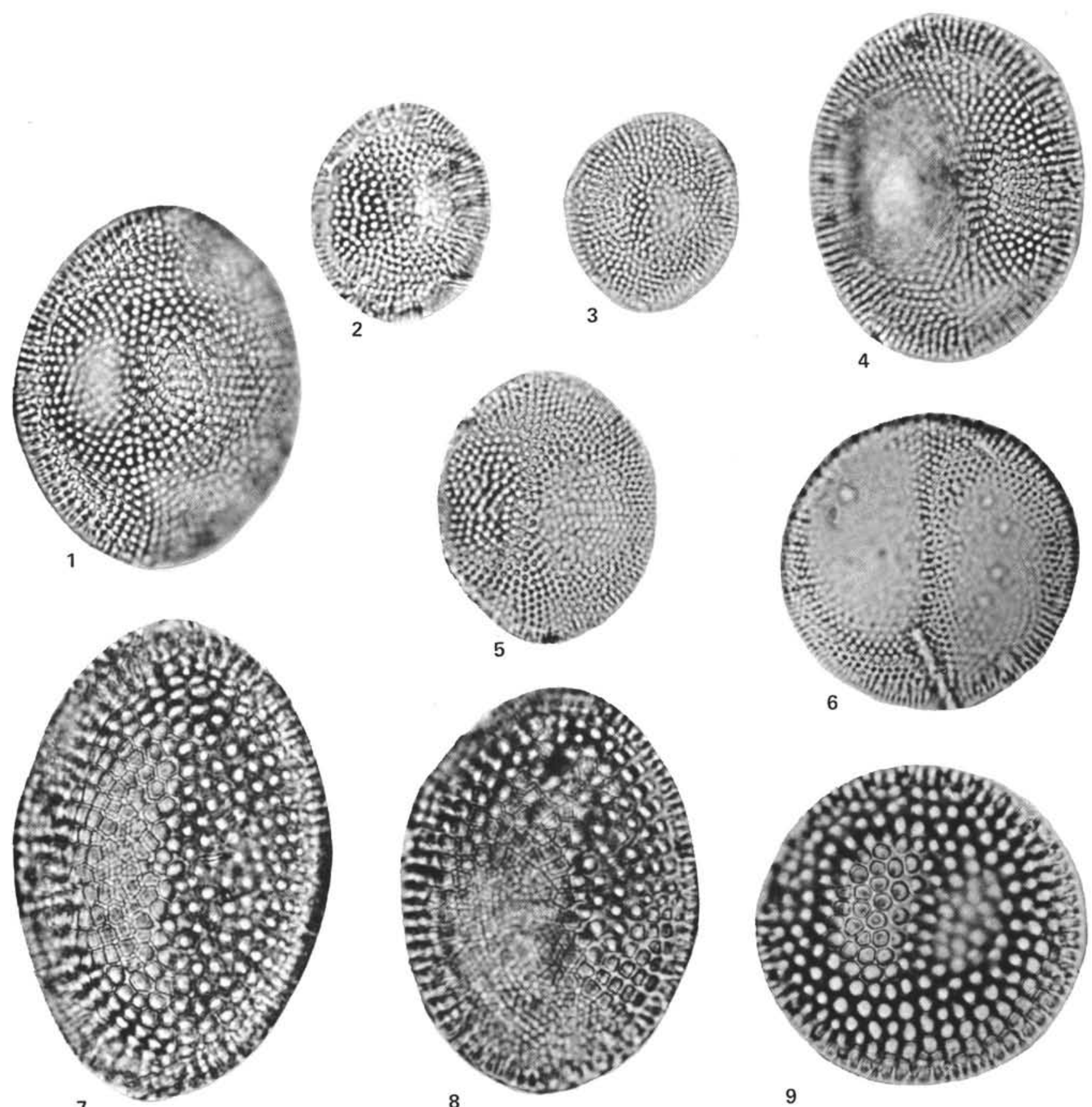

Plate 3. 1-5. Coscinodiscus temperei var. delicata n. var. (1) Holotype, USNM 304199, Sample 158-27-6, 30-32 cm, length $33 \mu \mathrm{m}$. (2) Sample $472-7-1,77-79 \mathrm{~cm}$, length $23 \mu \mathrm{m}$. (3) Isotype, USNM 304200, Sample 158-27-6, 30-32 cm, length $18 \mu \mathrm{m}$. (4) Isotype, USNM 304201 , Sample 158-27-6, 30-32 cm, length $32 \mu \mathrm{m}$. (5) Sample 472-6-5, 10-12 cm, length $25 \mu \mathrm{m}$. 6. Coscinodiscus plicatus Grunow s. ampl. Sample 472-8-2, 120-122 cm. Diameter $31 \mu \mathrm{m}$. 7-8. Coscinodiscus temperei var. temperei Brun. (7) Sample 438A-43-5, 135-137 cm, length $43 \mu \mathrm{m}$. (8) Sample 438A-34,CC, length $38 \mu \mathrm{m}$. 9. Coscinodiscus yabei Kanaya. Sample 469-20-3, 80-82 cm. Diameter $34 \mu \mathrm{m}$. 

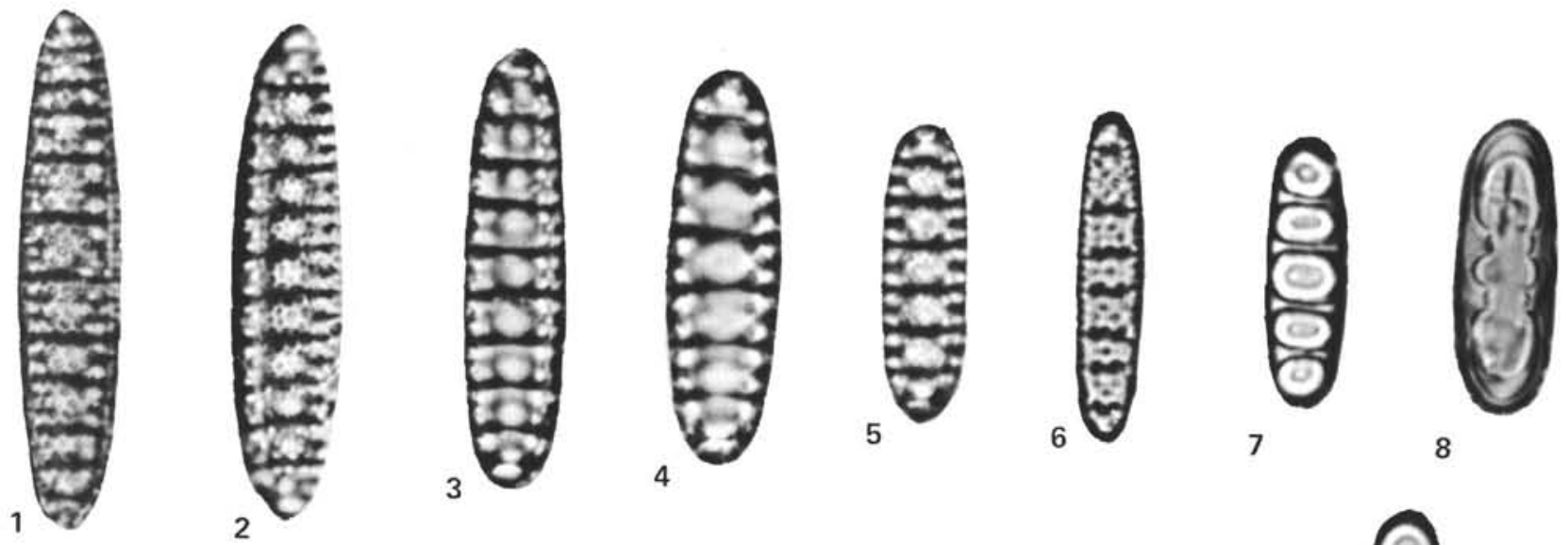

4
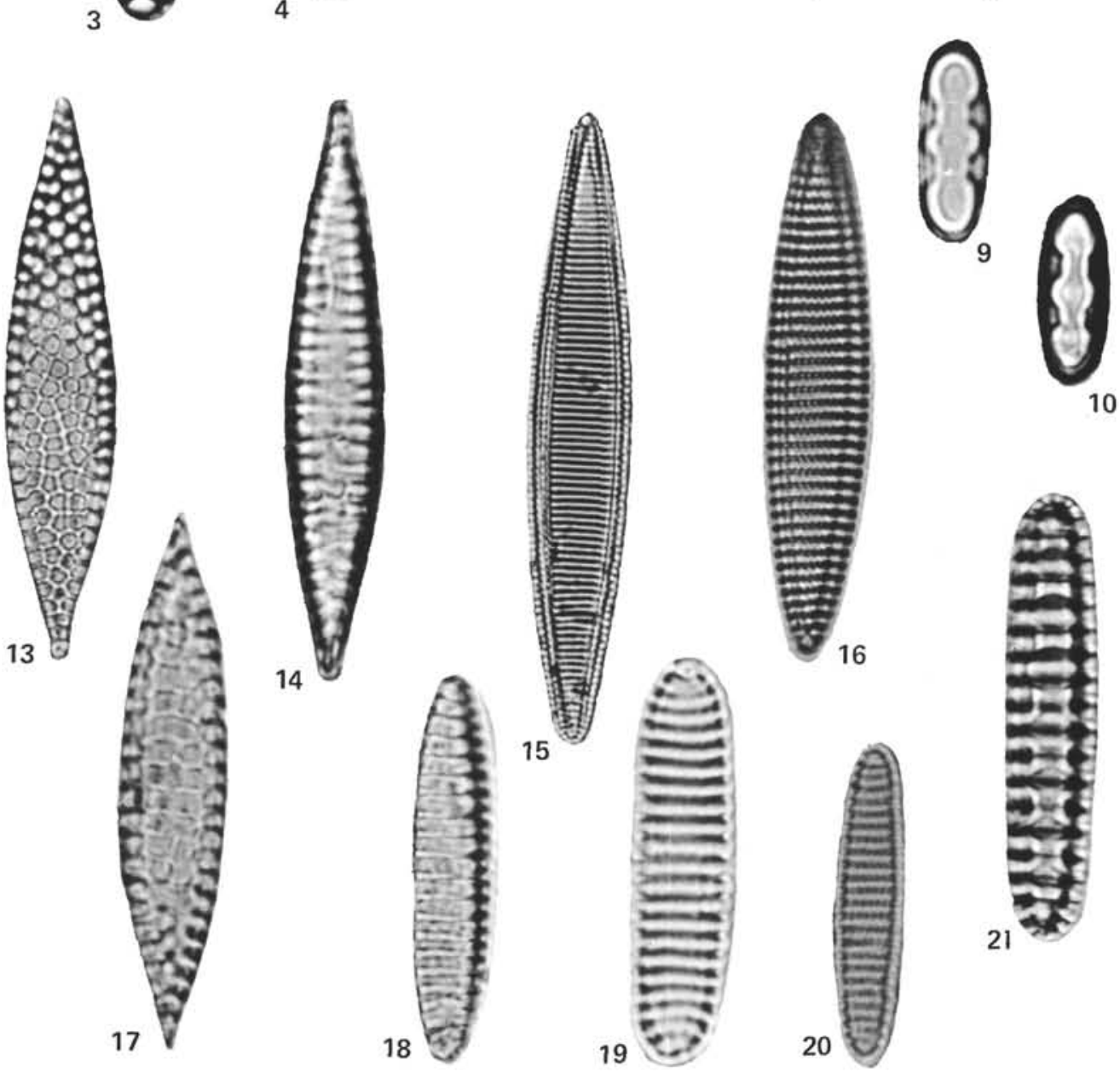

8

Plate 4. 1. Denticulopsis punctata var. hustedtii (Schrader) Simonsen. Sample 472-7-3, 38-40 cm. Length $31 \mu \mathrm{m}$. 2. Denticulopsis sp. (spore?). Sample 469-20-3, 80-82 cm. Length $28 \mu \mathrm{m}$. 3-4. Denticulopsis hyalina (Schrader) Simonsen. Sample 470-17-3, 79-80 cm. Length $31 \mu \mathrm{m}$ (3), 23 $\mu \mathrm{m}$ (4). 5. Denticulopsis lauta (Bailey) Simonsen. Sample 469-16,CC. Length $15 \mu \mathrm{m}$. 6. Denticulopsis nicobarica (Grunow) Simonsen. Sample 469-23-3, 17-19 cm. Length $20 \mu \mathrm{m}$. 7. Denticulopsis dimorpha (Schrader) Simonsen. Sample 469-16,CC. Length 19 $\mu \mathrm{m}$. 8-10. Denticulopsis praedimorpha (Akiba), n. comb. (8, 10) Sample 469-19-1, 40-42 cm, lengths $18 \mu \mathrm{m}$ and $12 \mu \mathrm{m}$. (9) Sample 469-19,CC, length 14 $\mu \mathrm{m}$. 11-12. Bogorovia paleacea var. elongata, n. var. (11) Holotype, USNM 304198, Sample 77B-15-6, 23-25 cm, length $65 \mu \mathrm{m}$. (12) Sample 472-7-6, 70-72 $\mathrm{cm}$, length $79 \mu \mathrm{m}$. 13. Bogorovia paleacea var. paleacea (Grunow) Jousé. Sample 472-10-1, 120-122 cm. Length 49 $\mu \mathrm{m}$. 14. Bogorovia praepaleacea (Schrader) Jousé. Sample 469-19-1, 40-42 cm. Length $38 \mu \mathrm{m}$. 15. Nitzschia reinholdii Kanaya and Koizumi. Sample 467-13-5, 40-42 cm. Length $79 \mu \mathrm{m}$. 16. Nitzschia praereinholdii Schrader. Sample 472-7-1, 10-12 cm. Length $51 \mu \mathrm{m}$. 17 . Bogorovia tatsunokuchiensis (Koizumi) Jousé. Sample 472-6-3, 40-42 cm. Length $36 \mu \mathrm{m}$. 18. Nitzschia rolandii Schrader. Sample 471-14-1, 20-22 cm. Length $27 \mu \mathrm{m}$. 19. Nitzschia challengeri Schrader. Sample 469-20,CC. Length $20 \mu \mathrm{m}$. 20. Nitzschia porteri Frenguelli sensu Burckle. Sample 469-14-2, 40-42 cm. Length $16 \mu \mathrm{m}$. 21. Denticulopsis hustedtii (Simonsen and Kanaya) Simonsen. Sample 470-17-3, 79-80 cm. Length 31 $\mu \mathrm{m}$. 

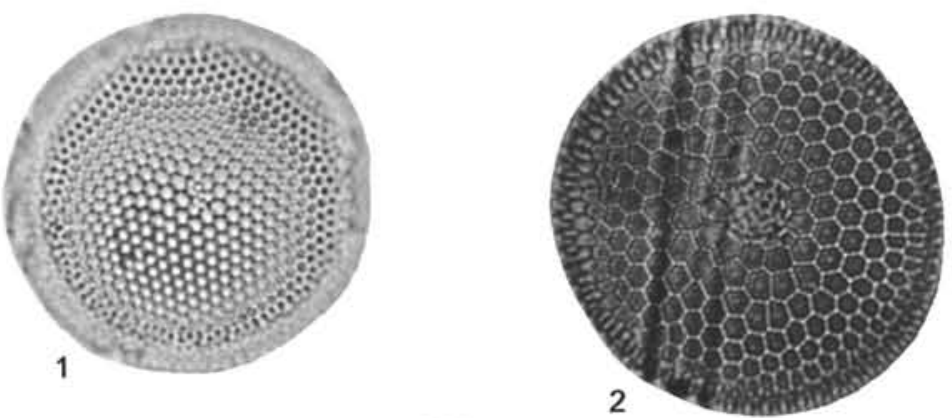

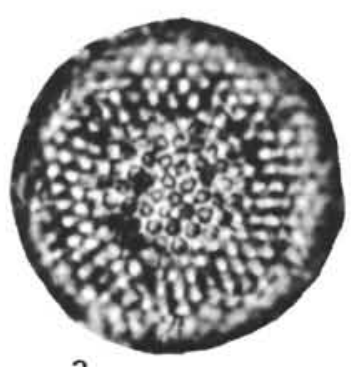

3
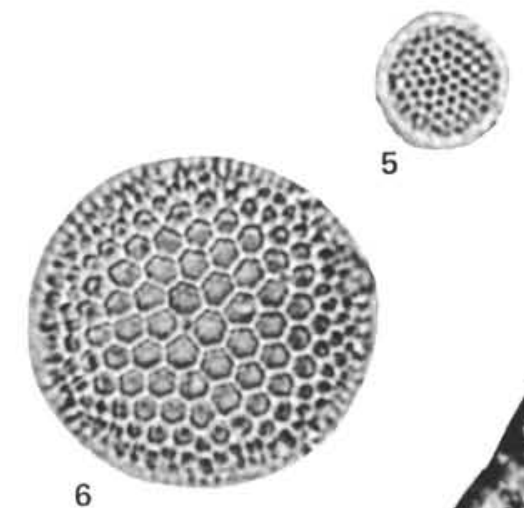

5
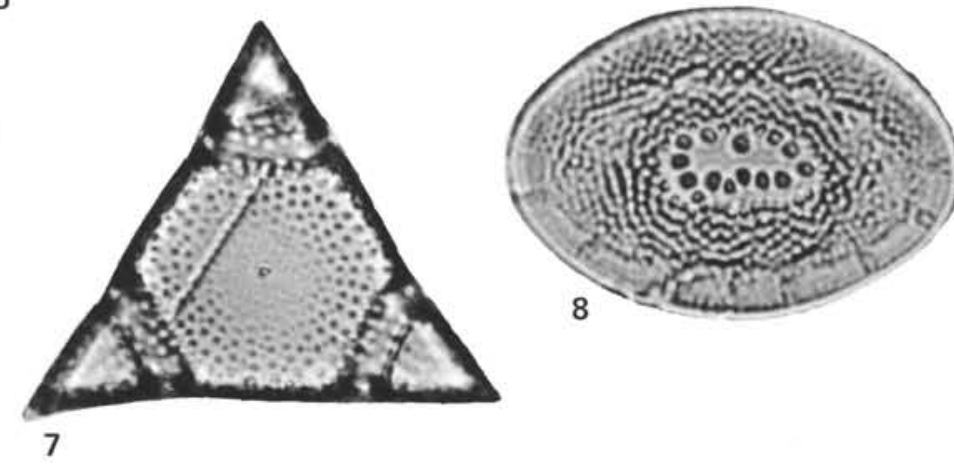

4
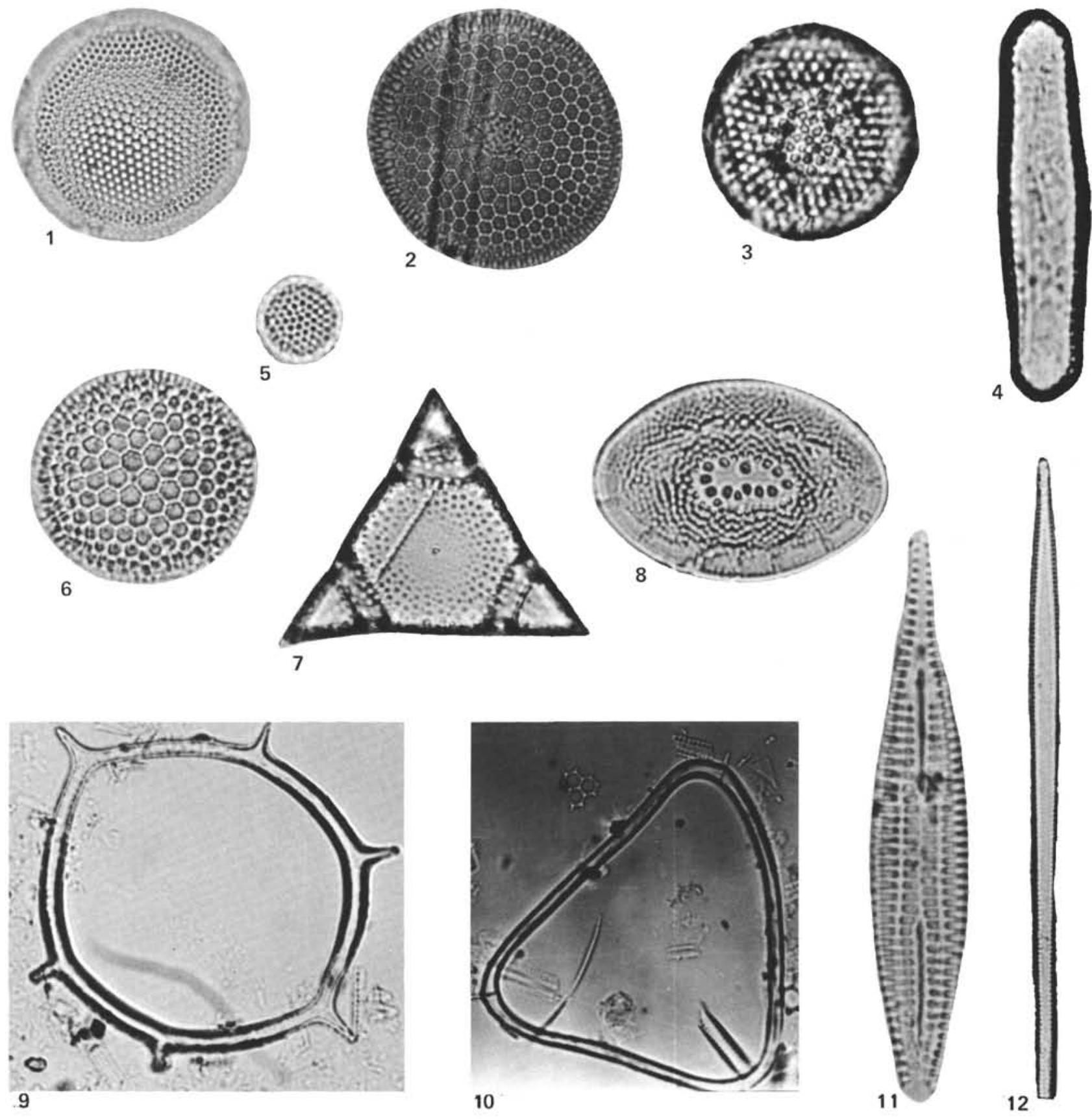

Plate 5. 1. Thalassiosira sp. 2. Sample 472-6-2, 40-42 cm. Diameter $28 \mu \mathrm{m}$. 2. Thalassiosira burckliana Schrader. Sample 472-6-4, 20-22 cm. Diameter $28 \mu \mathrm{m}$. 3. Thalassiosira miocenica Schrader. Sample 471-11-1, 20-22 cm. Diameter $23 \mu \mathrm{m}$. 4. Thalassionema hirosakiensis (Kanaya) Schrader. Sample 470A-4,CC. Length $36 \mu \mathrm{m}$. 5. Thalassiosira sp. 1. Sample 472-6-5, 10-12 cm. Diameter $8 \mu \mathrm{m}$. 6 . Thalassiosira oestrupii (Ostenfeld) Proshkina-Lavrenko. Sample 467-13-5, 40-42 cm. Diameter $30 \mu \mathrm{m}$. 7. Lithodesmium reynoldsii Barron. Sample 472-7-3, 38-40 cm. Length of base $31 \mu \mathrm{m}$. 8. Hemidiscus ovalis Lohman. Sample 472-7-5, 70-72 cm. Length $28 \mu \mathrm{m}$. 9. Mesocena hexalitha Bukry. Sample 470-12-1, 14-16 cm. Short diameter $56 \mu \mathrm{m}$. 10. Mesocena apiculata curvata Bukry. Sample 468B-15-1, 45-47 cm. Length of side 56 $\mu \mathrm{m}$. 11. Rouxia fusiformis Tsumura. Sample 469-16,CC. Length $51 \mu \mathrm{m}$. 12. Thalassiothrix sp. 1. Sample 469-5-5, 70-72 cm. Length $113 \mu \mathrm{m}$. 

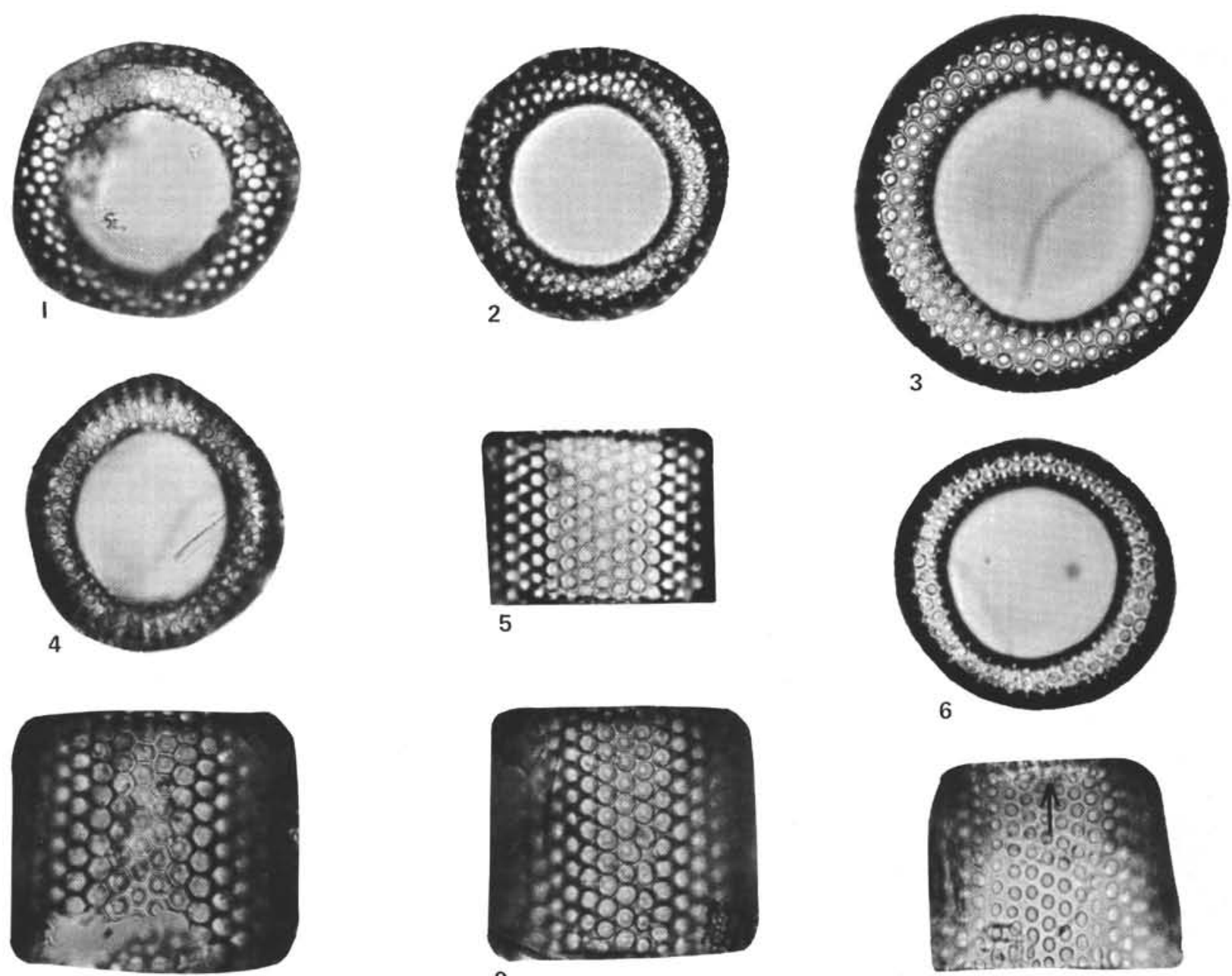

7

8

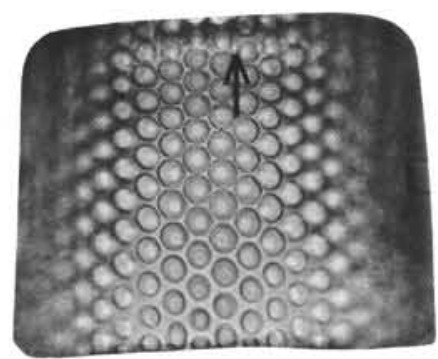

11

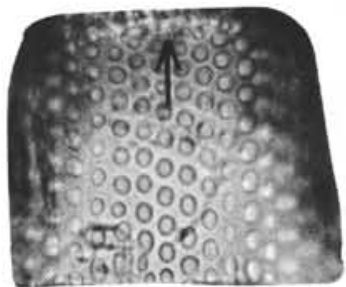

9

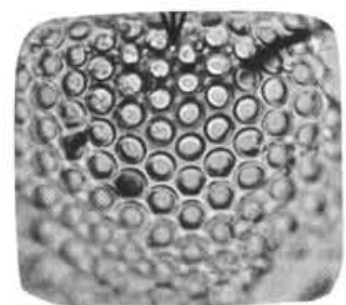

12

Plate 6. 1, 2, 5, 7, 8. Annellus californicus var. californicus Tempere. (1-2) View of valve surface. (1) Sample 472-11-3, 35-37 cm, diameter 46 $\mu \mathrm{m}$; (2) Sample Mf5192, dart core sample from southern California Continental Borderlands, diameter $50 \mu \mathrm{m}$. (5, 7, 8) View of valve margin. (5) Sample 472-11-3, 35-37 cm, height $43 \mu \mathrm{m}$; (7) Sample 472-11-1, 100-102 cm, height $40 \mu \mathrm{m}$; (8) Sample Mf5192, height 40 $\mu \mathrm{m}$. 3, 4, 6, 9-12. Annellus californicus var. hannai n. var. $(3,4,6)$ View of valve surface. (3) Adler $\# 424$ Solstice Canyon, southern California, diameter $49 \mu \mathrm{m}$; $(4)$ Isotype USNM 304195, Sample Mf5208, dart core sample from southern California Continental Borderland, diameter 51 $\mu$ m; (6) Sample Mf3150, dart core sample from the southern California Continental Borderland, diameter $52 \mu \mathrm{m}$. (9-12) View of valve margin. (9) Isotype USNM 304196, Sample Mf5208, dart core sample from the southern California Continental Borderland, height $46 \mu \mathrm{m}$; (10) Sample L-9, type area of the Luisian Stage, San Luis Obispo County, California, height $43 \mu \mathrm{m}$; (11) Sample Adler \#424, Solstice Canyon, height $49 \mu \mathrm{m}$; (12) Sample $468-10-3,70-72 \mathrm{~cm}$, height $43 \mu \mathrm{m}$. (Note single row of small pores between areolae below the top of the valve in Figs. 9-12.) 

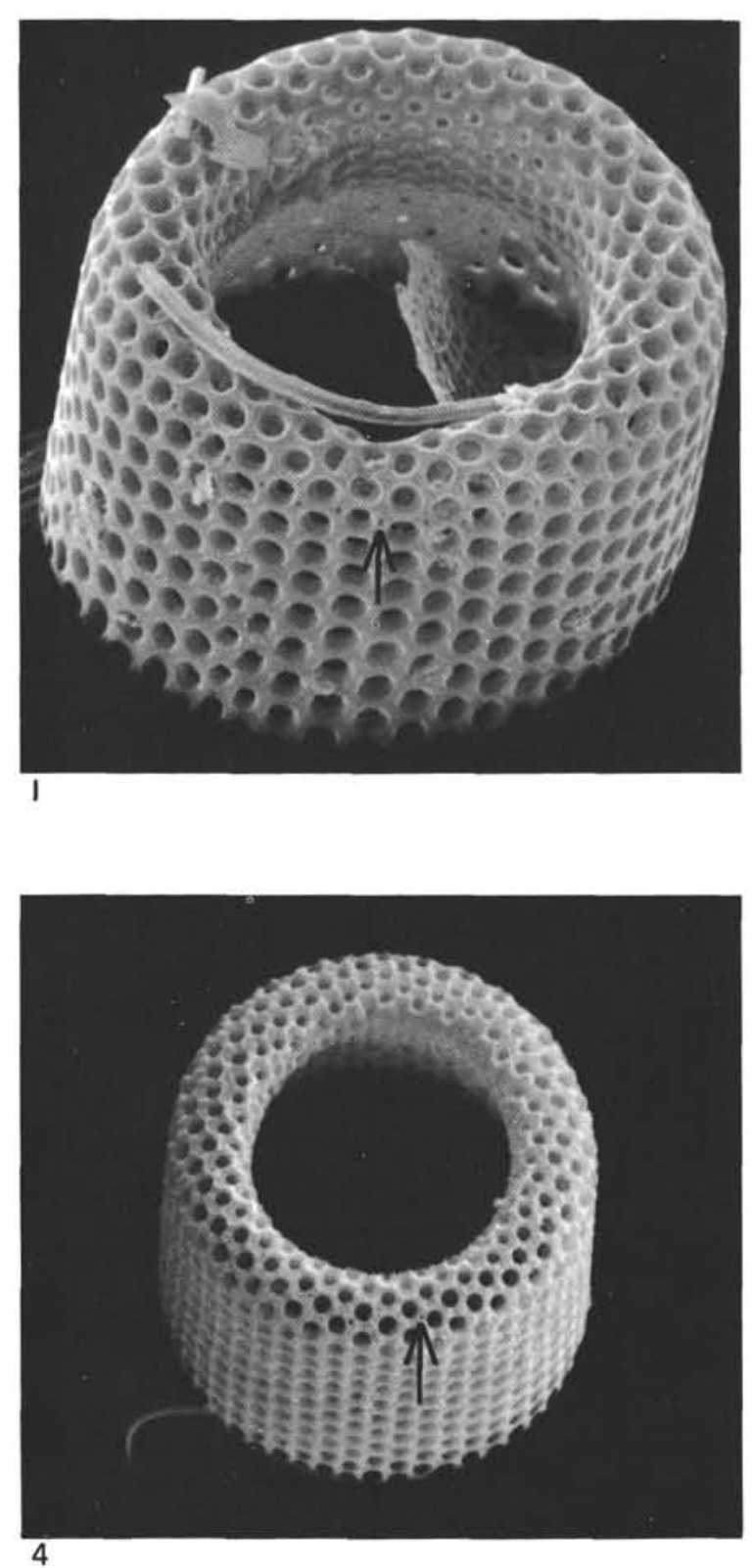

Plate 7. Scale bar equals $30 \mu \mathrm{m}$ except for 2, where it equals $3 \mu \mathrm{m}$. 1-3. Annellus californicus var. hannai, n. var. (1) Holotype USNM 304194, Sample Mf5208, southern California Continental Borderland, $33.196^{\circ} \mathrm{N}, 119.262^{\circ} \mathrm{W}$. Oblique view. Note the single row of pores between the areolae just below the top of the valve on the outer cylinder. Note also that the outer loculate wall is invaginated rather deeply (about $14 \mu \mathrm{m}$ ) into the interior of the cylinder. (2) Enlarged view of a portion of the holotype (1) showing the pores located between the areolae near the top of the valve. (3) Isotype USNM 304197, Sample Mf5208, view of the valve margin. 4, 5. Annellus californicus var. californicus Tempere. Sample Mf5192, southern California Continental Borderland, $32.352^{\circ} \mathrm{N}, 118.4 .4^{\circ} \mathrm{W}$. (4) Oblique view. Note that the outer loculate wall is only invaginated slightly $(4-5 \mu \mathrm{m})$ into the interior of the cylinder. Note also that pores between the areolae occur on the top of the valve-they cannot be seen in a marginal view. (5) View of valve margin. 